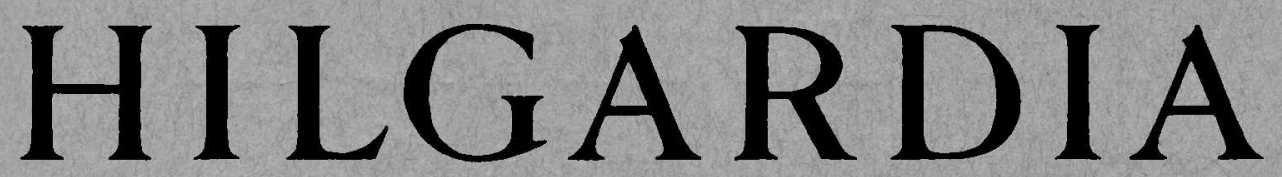

A Journal of Agricultural Science Published by the California Agricultural Experiment Station

\title{
FURTHER TESTS USING A POLYHEDROSIS VIRUS TO CONTROL THE ALFALFA CATERPILLAR
}

CLARENCE G. THOMPSON and EDWARD A. STEINHAUS 


\section{H I}

A Journal of Agricultural Science Published by

the California Agricultural Experiment Station

\section{FURTHER TESTS USING A POLYHEDROSIS VIRUS TO CONTROL THE ALFALFA CATERPILLAR ${ }^{1}$}

\section{CLARENCE G. THOMPSON ${ }^{2}$ and EDWARD A. STEINHAUS ${ }^{3}$}

\section{CONTENTS}

Summary . . . . . . . . . . . . . . . . . . . . . . 412

Introduction . . . . . . . . . . . . . . . . . . . . . 413

Preliminary field observations . . . . . . . . . . . . . . . 413

Laboratory experiments . . . . . . . . . . . . . . . . . 415

Obtaining virus-free larvae . . . . . . . . . . . . . . . 415

Nature of virus infection and transmission . . . . . . . . . 416

Dust versus spray . . . . . . . . . . . . . . . . . . 419

Conclusions of laboratory experiments . . . . . . . . . . . 419

1948 field tests . . . . . . . . . . . . . . . . . . . . 420

Preparation of virus material . . . . . . . . . . . . . . 420

Results of 1948 field tests . . . . . . . . . . . . . . . . . . . 421

1949 field tests . . . . . . . . . . . . . . . . . . . . 423

1949 field test 1 . . . . . . . . . . . . . . . . . . . 424

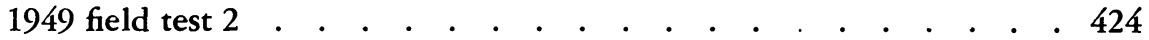

1949 field test 3: airplane application no. 1 . . . . . . . . . . 425

1949 field test 4 : airplane application no. 2 . . . . . . . . . . 426

Economics of virus control . . . . . . . . . . . . . . . . 427

Supply . . . . . . . . . . . . . . . . . . . . . . 427

Application . . . . . . . . . . . . . . . . . . . . 428

Literature cited . . . . . . . . . . . . . . . . . . . . 429

Figures and tables

${ }^{1}$ Contribution from the Laboratory of Insect Pathology, Division of Biological Control, College of Agriculture, University of California, Berkeley. Received for publication January 3,1950 .

2 Junior Insect Pathologist in the Experiment Station.

${ }^{3}$ Associate Professor of Insect Pathology and Associate Insect Pathologist in the Experiment Station. 


\section{SUMMARY}

The polyhedrosis of the alfalfa caterpillar, Colias philodice eurytheme Boisduval, is an important factor in the natural reduction of populations of the insect. Epizootics of the disease can be induced by artificial dissemination of the virus. This paper is a report of experiments and field tests conducted during 1947,1948 , and 1949, leading to the successful control of the caterpillar by artificial epizootics. The following general conclusions are the results of these experiments.

Natural epizootics of polyhedrosis cannot in general be depended upon to occur regularly enough to give satisfactory economic control of the caterpillar. Usually they occur only after serious damage to the alfalfa has already been done. Moreover, it is unlikely that natural epizootics can be induced at will through cultural practices.

Natural epizootics are apparently initiated by a complex of factors. One of the most significant of these seems to be population density. Climatic conditions are important primarily because of their effect upon the caterpillar population.

Virus infection and transmission: The virus may be transmitted by a number of mechanical factors including: contaminated adult Colias, insect parasites, carnivorous insects, wind, rain, and irrigation water. Passage of the virus via the egg apparently occurs by external contamination.

Temperature has seemingly little effect on the susceptibility of the insect to infection, but the length of the incubation period of the disease in the insect appears largely determined, within limits, by temperature. Within the temperature ranges tolerated by the caterpillar, the incubation period is shorter at higher temperatures and longer at lower temperatures. Temperature is also an important factor in determining population densities of the host.

Relative humidity does not appear to have much effect on the susceptibility of the host to the infection, or on the incubation period of the disease. It is important, however, in its effect on the population density of the caterpillar.

Application: Application of a virus suspension containing 5,000,000 polyhedra per milliliter at the rate of five gallons per acre appears adequate to insure infection of a field population and its reduction to below economic levels, at least under the conditions usually encountered in the northern San Joaquin Valley.

Application by airplane appears to be one of the most convenient means of treating most fields with a virus suspension. Small fields may be more suited to application by ground equipment.

Economics of control: Virus material can be prepared in large quantities at relatively little expense, and can be preserved at least two years. Cost of application itself is essentially the same as that of an insecticide application. 
Recommendations as to the general use of the virus as a means of practical control of the caterpillar cannot be made until further tests have been completed. In any case, its use will probably require competent supervision by trained entomologists.

\section{INTRODUCTION}

DURING THE PAST three years a concentrated effort has been made to study the epizootiology and possible applications of a polyhedrosis occurring in the alfalfa caterpillar, Colias philodice eurytheme Boisduval. Already published (Steinhaus, 1948, 1949a, $b$; Steinhaus and Thompson, 1949) ${ }^{\star}$ are the essential characteristies of the disease, information on the nature of the causative virus (Borrelina campeoles Steinhaus), and the results of preliminary field tests using the virus to control the alfalfa caterpillar. Remaining to be published are (1) the results of a number of laboratory experiments pertinent to the conduct of the field tests, and (2) the results of 1949 field tests including the use of aircraft to aid in the control of the caterpillar. The present paper deals largely with these two aspects of the general investigation.

\section{PRELIMINARY FIELD OBSERVATIONS}

From general field observations made during 1947 and 1948 in the northern San Joaquin Valley of California, the disease was found to occur only rarely during the early summer months. It became more common during the middle of the summer, and during August and September widespread epizootics were observed in several fields. Even in late summer, however, some fields developed large populations with little or no trace of the disease. It became apparent that some factor or factors must be responsible for the occurrence of epizootics in some fields and their absence in others, so a number of fields were followed closely in an effort to determine the cause of this phenomenon.

One of the striking characteristics of a severe epizootic is the uniformity with which it strikes the entire population of a field. Almost all larvae in a particular field are in approximately the same stage of the disease at the same time, indicating that they must all have been infected at about the same time. On the other hand, larvae in near-by fields with approximately the same caterpillar populations, and with alfalfa in similar stages of growth, may be almost free from the disease. In still other fields, the disease may take an enzootic form, a certain percentage of the population being infected but with no appreciable increase in the rate of infection.

By the end of the season it was possible to eliminate temperature, humidity, climatic conditions in general, and stage of growth of the alfalfa at the time of the epizootic from the list of factors directly responsible for initiating an epizootic, since all of these were uniformly present in many of the fields followed-those in which epizootics developed, and those in which they did not. In some cases, population densities were similar, although, as a rule, severe epizootics did not develop in fields with low caterpillar populations. Most of the literature on the subject is uniform in agreeing that high temperature and high humidity are favorable to an outbreak of the disease, and

\footnotetext{
"See "Literature Cited" for citations, referred to in the text by author and date.
} 
that proper timing of irrigation will initiate the disease. Since the observations made by the authors eliminated temperature and humidity as apparent direct factors, particular attention was directed to the effect of irrigation.

In an effort to find out if the virus is naturally present in the field debris and surface soil, sprigs of virus-free alfalfa were dipped in water suspensions prepared from these materials and fed to healthy caterpillars. Similar tests were made with larvae fed alfalfa dipped in irrigation water standing in the field. Virus was demonstrated to be present in all of these materials. Since irrigation is a factor which affects a field more or less uniformly, it was strongly suspected that this was the element responsible for the uniformity of epizootics. During the summer months, alfalfa fields in the San Joaquin Valley are usually irrigated at least twice between each cutting. Investigation showed that in every epizootic observed, irrigation occurred one to two weeks before the outbreak of the disease. This period approximates the incubation period of the disease. Further investigation, however, revealed that some fields with large caterpillar populations were irrigated at the same time and yet no epizootic occurred.

Apparently some factor in addition to irrigation is involved. While it has not been conclusively demonstrated, it is probable that the stage of growth of the alfalfa at the time of irrigation is another factor in the complex. Some fields show no fresh growth after a cutting until after the first irrigation. Other fields may show growth suitable for oviposition by adult female Colias before the first irrigation. If no part of the alfalfa plant with which the caterpillars are likely to come in contact is covered by the irrigation water, it does not appear probable that the larvae will become infected. The same may apply to the second irrigation, although in a somewhat different fashion. In some fields the alfalfa is so tall that only the stems at the base of the plant come in contact with the water. In other fields, the lower leaves of alfalfa which has grown less rapidly may be contaminated by the water. Here again the possibility of contamination of the leafy part of the plant might be suggested as the critical factor.

In brief, the 1947-48 field observations indicate the following:

1. Natural epizootics are most likely to occur in the latter part of the summer when population densities of the caterpillar are ordinarily the highest. Although it appears that high populations of the caterpillar are usually necessary before an epizootic will break out, infected individuals are found in populations of low density.

2. Epizootics in nature are usually very uniform throughout a field, most of the caterpillar population (also rather uniform) being at approximately the same stage of the disease at any given time.

3. Unless weather conditions are such as to cause the caterpillars to drop to the ground, climatic factors probably have little, if any, direct effect in initiating an epizootic. On the other hand, climatic conditions do influence the density of the insect population, and it is when the population density is high that an epizootic is most likely to occur naturally. Thus climate may be said to have an indirect influence on the initiation of an epizootic.

4. Population density, and the stage of growth of the alfalfa at time of irrigation are probably important factors in initiating an epizootic. 
5. Enzootics may occur. The exact reason for the failure of the disease to spread naturally in some fields has not been determined. Enzootics seem to appear mainly in sparse, dry fields with small or moderate caterpillar populations, although exceptions have been observed.

\section{LABORATORY EXPERIMENTS}

\section{Obtaining Virus-Free Larvae}

The field observations made during $1947-48$ as well as the preliminary field tests of 1948 revealed several problems lending themselves to laboratory experimentation. Our first attempts to rear larvae for laboratory experiments, however, quickly brought out the fact that some of the field-collected, apparently healthy larvae contained the virus and were in the early stages of the disease. The disease proved to be so virulent that any group of larvae containing an infected individual would eventually become almost 100 per cent infected by the virus. In addition, the collecting net would invariably become contaminated through sweeping for test larvae. To avoid these difficulties, as well as to provide a constant source of supply, adult Colias were brought in from the field, confined in cages, and allowed to oviposit on potted alfalfa.

The groups of larvae reared from these eggs died of the virus disease. Investigation determined that the adult females were laying a certain number of eggs which were either infected internally or contaminated externally.

Egg Sterilization: Since a source of dependably healthy stock appeared necessary to carry out laboratory studies, experiments were set up to determine the possibility of sterilizing the eggs without killing the embryo. While adult females collected in the spring laid eggs of which only 5 per cent developed into diseased larvae, by fall the incidence of infection had risen to as high as 30 per cent. These figures represent the entire mortality occurring in the sample from the time the eggs hatch until the end of the pupal stage. The crowded conditions of laboratory rearing appear to increase the percentage of infection over that occurring in the field. Nevertheless, the seasonal variation of the rate of infection obtained in the laboratory probably also applies to the situation in the field. Since the stock collected for egg sterilization experiments was taken in the fall of the year, the rate of infection was high.

Bergold (1942) reported that the nun moth, Porthetria dispar Linn., also oviposits a certain percentage of contaminated eggs. He found that 30 per cent trichloracetic acid for 15 minutes completely inactivated virus (Borrelina efficiens Holmes) on the surface of the egg. However, duplication of Bergold's work, using Colias eggs and Colias virus, resulted in essentially negative results. Consequently, an experiment was set up to test the efficacy of a number of common disinfectants. The results of these tests, shown in table 1 , indicate that of the materials used, only formaldehyde is effective in destroying the alfalfa-caterpillar virus. The treatment finally selected was immersion of the eggs in 10 per cent formaldehyde, by weight, for 90 minutes. Since a very small percentage of the treated eggs still develop into diseased larvae, it has been found expedient to rear test larvae in individual containers, although for certain experiments they can be reared in groups of 10 or less. 


\section{Nature of Virus Infection and Transmission}

Temperature: Because field observations indicated that temperature is an important factor in the incubation period of the disease, and since most workers have reported that the development of epizootics of the disease in the field are dependent upon high temperatures, an experiment was performed to determine the importance of temperature on the initiation and the course of an epizootic. Forty third-instar larvae were placed individually in petri dishes. Twenty were fed alfalfa dipped in a virus suspension, and 20 were fed clean alfalfa as a control. All 40 were placed in a cold incubator at $10^{\circ} \mathrm{C}$. Nineteen of the treated group and 2 of the control group died of virus after an average incubation period of 23 days. Six of the treated group and one of the control group died from non-virus causes. None of the virus-treated group survived, while 17 of the control group completed their development to the adult stage.

When the experiment carried out at $10^{\circ} \mathrm{C}$. was completed, a similar test was run at $15^{\circ} \mathrm{C}$. All of the virus-treated larvae died of the virus. The average incubation period was 11 days. None of the control group died of virus. The same test, performed at $20^{\circ} \mathrm{C}$., resulted in complete mortality from the virus disease in the treated group with an average incubation period of 7 days. One of the control group died of virus. At $25^{\circ} \mathrm{C}$., 100 per cent mortality due to virus infection resulted in the treated group in an average time of 6 days after infection; while at $30^{\circ} \mathrm{C}$., all the treated larvae died in from 4 to 5 days from the virus. There was no mortality from virus infection in either. control group in these two tests. At temperatures over $33^{\circ} \mathrm{C}$., bacterial infection killed the test larvae before it was possible to diagnose for the polyhedrosis. At $33^{\circ}$ C., the average time from infection to death by the polyhedrosis was 4 days.

The results of this experiment indicate that within the temperature range in which the host insect is active, susceptibility to infection is independent of the temperature; however, temperature is of great importance in its effect upon the incubation period of the disease. This fact is of importance in the field as it demonstrates that the length of time required for mortality will vary with the temperature. Observations made throughout the test indicate that the optimum temperature range for the caterpillar includes the optimum for the virus. Larvae originally of the same size but maintained at different temperatures after infection were about the same size at death, even though the group at the lower temperature required a much longer incubation period than the other. The host-parasite association is obviously very close, and it is quite possible that the rate of growth of the caterpillar determines that of the virus.

Humidity: Since a condition of high humidity has generally been reported as necessary before an epizootic can occur, an experiment to determine the importance of this factor was devised. Twenty larvae were set up in small individual screen cages in a desiccator. As some transpiration of moisture through the leaves of the alfalfa used as food for the test insects was unavoidable, all the moisture could not be removed from the air; however, the relative humidity was so low that 5 of the test larvae died, apparently of desiccation. 
The food of the larvae was dusted with dried virus material. All 15 larvae that survived desiccation died of polyhedrosis 7 days after inoculation.

To test the opposite extreme humidity, 20 larvae were placed in individual cages in a chamber in which a relative humidity of approximately 100 per cent was maintained. Of this group, 12 larvae died within 4 days from bacterial infection. All of the remaining 8 caterpillars died of polyhedrosis 7 days after their food had been dusted with dried virus material. Both tests were conducted at room temperature (approximately $22^{\circ} \mathrm{C}$.). No deaths from virus infection occurred in the control group.

It would appear, from the results of this experiment, that relative humidity has little, if any, direct effect upon either the susceptibility of the larvae to infection or the incubation period of the virus. As with temperature, the importance of humidity appears to be largely in its effect upon the health and growth of the host caterpillar. Favorable temperature and humidity over an alfalfa-growing region are links in the chain of factors which permit the insect population in a particular field and cutting to increase to a point where an epizootic can break out.

Wind Transmission: To test the possibilities of wind transmission of the virus in the field, a group of infected larvae were allowed to die on alfalfa growing in a flat. A flat of clean alfalfa was then placed adjacent to the contaminated one, and a fan placed to blow across the contaminated flat to the clean one. The wind velocity was approximately 4 miles per hour at one foot from the fan and 2 miles per hour at 6 feet from the fan. The clean flat was replaced 3 times at 3 -day intervals. The soil in the flats was kept moist. Alfalfa clipped from each clean flat after exposure was fed to 20 healthy test larvae set up in individual cartons. Twelve larvae of the group fed alfalfa from the first exposure died from virus. None of the larvae fed alfalfa from the last two exposures died of polyhedrosis. Close observation indicated that the cadavers of the freshly dead larvae, being fragile and liquefied, had a tendency to splatter under the influence of the air currents and the whipping action of the alfalfa. Once the cadavers had dried and hardened, no transmission appeared to occur. Varying the distance between the contaminated and clean flats indicated that about 2 feet is the limit of transmission under these conditions. Mixing material from virus-killed caterpillars with soil, allowing the mixture to dry, and-blowing an air current across the soil onto clean alfalfa as much as 6 feet away caused the alfalfa to become infectious. Conditions similar to the above probably occur in the field and undoubtedly account for some localized transmission of the disease.

Vascular Transmission in Plant: In order to test the possibility of transportation of the insect virus from the surface soil and debris to the alfalfa leaves by the vascular bundles of the plant itself, a potted alfalfa plant was watered daily with a water suspension of the virus for a period of 7 days. Care was taken not to contaminate the foliage. The leaves of this plant were then fed to 20 larvae reared in individual cartons. None of the test or control insects developed the disease. In a further test, cut alfalfa was placed in a flask containing a water suspension of the virus in such a manner that the leaves could not become mechanically contaminated. The tips of alfalfa were clipped off and fed to 20 individually reared larvae. All of the test larvae 
died of polyhedrosis while only one of the untreated control larvae died of the disease. The results of this experiment indicate that the alfalfa plant in the field will not normally transport the virus from the soil, although mechanical injury to the plant may make occasional transmission possible.

Transmission by Parasite: Another means of mechanical transmission is suggested in a common parasite of the alfalfa caterpillar, Apanteles medicaginis Muesebeck, which often affords satisfactory control of the caterpillar. Ordinarily, it parasitizes only the first three larval instars. This is in contrast to the virus, which, in nature, is usually found in nearly mature fifth-instar larvae. At the peak of a severe epizootic, however, the virus is found killing larvae of all instars except the first and early second. Since the parasite larvae ordinarily mature and emerge from late third-instar Colias larvae, the virus may act to reduce beneficial parasite populations. On the other hand, the possibility is suggested that adult parasites ovipositing in infected larvae may themselves become contaminated and serve as vectors of the virus.

In order to test this possibility, the following experiment was conducted: 20 second-instar Colias larvae, which had been infected with polyhedrosis 4 days previously, were placed in individual test tubes. An adult female Apanteles was added to each tube and allowed to remain until it had stung the caterpillar. The Apanteles were then transferred to 20 sterile test tubes, each containing a single healthy larva. At one-hour intervals, the parasites were removed and added to another series of tubes containing healthy caterpillars. Four series of healthy larvae were thus exposed to the parasites.

Of the first series of 20 healthy larvae parasitized, 16 developed polyhedrosis. Only two parasites were able to complete their development before their hosts died of the disease. Four caterpillars did not develop polyhedrosis, and their parasites developed normally. A series of 20 larvae exposed to uncontaminated adult female Apanteles was used as a control for the entire experiment. Of the control, one caterpillar died of the virus before its parasite could mature, while the other 19 produced mature parasites and showed no signs of the disease. Eight caterpillars of the second series developed polyhedrosis, while only three of the third and none of the fourth series died of the virus. From this experiment, it appears probable that adult Apanteles may be instrumental in establishing foci of infection throughout the field from which the disease may spread by other means, but without completely eliminating the insect parasite population. It is assumed that this infection occurs primarily as the result of stinging with the contaminated ovipositor. It is also possible, however, that the exterior of the bodies of the Apanteles parasites become contaminated and that the virus thus acquired is spread mechanically over the food plant of the caterpillar.

Other Vectors: The great virulence of the disease enhances the possibility of mechanical transmission by other vectors. An experiment was performed in which ants were allowed to feed on a virus-dead larva placed on a leaf of alfalfa on an otherwise uncontaminated plant. The rest of the plant then proved to be infectious when fed to healthy larvae. The ants in searching over the rest of the plant had apparently carried the virus with them. Certain carnivorous insects feed on caterpillars dead or dying of the virus, and numer- 
ous phytophagous insects which frequent alfalfa also may serve to disseminate the virus mechanically.

Survival: The virus does not need continuous host populations in the field to maintain itself. Infectious material containing polyhedra when smeared on glass slides and exposed to the weather has proved virulent after a period of two years. Whenever a caterpillar population arises in a field, the virus is probably already abundant in the surface soil and debris. If the virus is transported to the leaves on which the larvae feed, they will, in all probability, acquire the disease. In new alfalfa fields, of course, the virus is brought in by contaminated adult Colias, by parasites, and by such mechanical factors as wind-borne dust, irrigation water, predaceous insects, etc.

\section{Dust versus Spray}

In anticipation of field-testing the artificial dissemination of the virus, a water suspension applied as a spray was compared with a dust application. Each preparation was tested against 25 individually raised third-instar larvae. Ten milliliters of a virus suspension containing 50,000,000 polyhedra per milliliter were sprayed over 20 sprigs of alfalfa which were fed to one group of test larvae. Ten grams of virus dust containing 50,000,000 polyhedra per gram were dusted over 20 sprigs of alfalfa which were then fed to the second group of test larvae. The sprigs of alfalfa were laid in a row 6 inches apart when they were treated. Approximately one day less was required for virus-caused mortality in the larvae fed sprayed alfalfa than in those fed dusted alfalfa. While the results of this one experiment may not be of much significance, it was decided to apply the virus as a spray in the summer field tests since sprays in general are ordinarily found to provide more effective coverage.

\section{Conclusions of Laboratory Experiments}

The laboratory experiments performed were designed to give an insight into the fundamentals of the problem and to lay the groundwork for testing the practicability of artificial distribution of the virus in the field as an economic control measure for the alfalfa caterpillar. These experiments established the following points :

1. A certain percentage (in this study, 5 to 30 per cent) of the eggs laid by the adult butterflies is contaminated with virus. This percentage increases as the season advances. The contamination is apparently external.

2. Temperature and humidity apparently do not directly influence the susceptibility of the insect to infection by the virus. However, when these two factors are optimum for the insect, the host population increases to a point where an epizootic may break out provided the other necessary ecological factors prevailing in the alfalfa-growing region are favorable. Unfavorable temperature and humidity may reduce the host population to a point where an epizootic is not likely to occur. The incubation period of the disease is reduced by rises in temperature. The optimum temperature for both disease and insect appears to be in the neighborhood of $33^{\circ} \mathrm{C}$.

3. Wind may be a factor in transporting the virus either on dust or as a spray, at least for limited distances. 
4. The virus is not normally transported from the soil to the leaves of the alfalfa plant through the vascular tissues of the plant itself, although this may possibly occur when the plant root is mechanically injured.

5. Apanteles medicaginis Mues., a parasite of early-instar larvae, is probably important in establishing foci of infection throughout the field by mechanical transmission of the virus on the ovipositor.

6. To some extent, carnivorous insects probably spread the virus after feeding on dead or dying caterpillars.

7. Virus material may remain virulent after two years' exposure to the weather, and thus is not dependent upon a continuous host population to retain its infectious qualities.

8. Virus material preserved in a thick fluid form and applied as a spray apparently acts somewhat more quickly than virus material stored in a dried condition and applied in a similar concentration as a dust.

\section{FIELD TESTS}

The laboratory experiments and field observations made during 1947 and 1948 indicated that the most feasible solution of the problem of controlling the alfalfa caterpillar by means of a polyhedrosis virus is through artificial dissemination of the virus rather than attempting to induce natural epizootics through cultural practices. During the course of these studies on the etiology and epizootiology of the disease, the possibility of initiating the epizootic earlier than it begins naturally was suggested. With the exception of a superficial effort in South Africa (Lounsbury, 1913) the literature contains no account of an attempt to use a virus disease in the control of a crop pest. There was, therefore, no reliable assurance that the artificial distribution of the virus could be conducted in a manner which would reduce the population of the caterpillar to a point below that of economic importance. Futhermore, no satisfactory data were available as to whether or not an epizootic could be initiated in populations of relatively low densities, since natural epizootics are most apparent at times of high population densities.

Before conducting extensive field tests for the purpose of obtaining information on these questions, it was decided to conduct a few preliminary experiments of a purely exploratory nature. This was accomplished during the summer of 1948. A preliminary report of the 1948 field tests has already been published by Steinhaus and Thompson (1949) and the next few paragraphs are a brief recapitulation of this report.

\section{Preparation of Virus Material}

Since a method of cultivating insect viruses on artificial media has not yet been devised, it was necessary to find other means of producing the agent of alfalfa-caterpillar polyhedrosis in quantities great enough to be used for distribution in the field. Furthermore, as far as has been demonstrated, only the alfalfa caterpillar is susceptible to the particular virus with which we are concerned. Therefore, the only practical method of producing the virus was by infecting alfalfa caterpillars, permitting the virus to increase in their tissues, and then gathering and processing their infected bodies. 
Although it would be feasible to rear the Colias larvae in large numbers in the insectary, and then to infect them, for the experiments herein reported it was found more convenient to gather the caterpillars from naturally infested fields. They were brought into the laboratory and placed within large barriers on rearing trays, where they were crowded together with previously infected individuals. In a few days nearly all were dead or dying from the polyhedrosis. Their infected bodies were collected periodically, placed in large glass vials, and then held in the refrigerator until needed.

In preparing the infectious material for field distribution, the larvae, which for the most part had disintegrated and were in a semi-fluid condition, were blended into a thick homogenous suspension in a Waring blender. The material was then diluted 1:3 with distilled water, passed through cheesecloth to remove large particles, and a hemacytometer count made of the approximate number of polyhedral bodies in the suspension. Since there is undoubtedly some free virus (i.e., virus not included in the polyhedral bodies) in such a suspension, the use of polyhedra counts to. ascertain the concentration of virus activity is probably open to error and only approximates the amount of virus present. Nevertheless, the polyhedral count is a convenient means of arriving at this approximation.

The concentrated infectious material was taken into the field and then further diluted so that the polyhedral count of the final spray solution was between 50,000,000 and 100,000,000 per milliliter. The final dilution was determined by calculation from the earlier hemacytometer count. An ordinary 5-gallon back-pack hand sprayer was used for application. The spray was directed uniformly over the alfalfa.

\section{Results of 1948 Field Tests}

To ascertain the possible practical value of distributing the virus artificially, four separate tests were conducted during the summer of 1948 (Steinhaus and Thompson, 1949) on plots situated in alfalfa fields in central California in the Westley-Patterson area (northwest portion of the San Joaquin Valley). Comparable plots in the same fields were established as untreated controls. In all cases, the end of the experiment was dictated by the cutting of the field by the grower. The pertinent information pertaining to each plot is reviewed as follows:

Plot 1 . The size of test plot 1 was 20 by 400 feet; that of the control plot was the same. One gallon of virus suspension $(97,000,000$ polyhedra per milliliter) was applied to the alfalfa in this plot. The population of 58 larvae per 10 sweeps at the time of application of the virus rose to 154 per 10 sweeps in the control plot in 15 days. In the plot treated with virus suspension, the larval count remained parallel to that of the untreated plot during the incubation period of the disease and then fell to 4 per 10 sweeps in 15 days. The counts paralleled each other for 6 days, the approximate incubation period of the disease. That the mortality was caused by the virus is indicated by the fact that practically 100 per cent of the larvae in the test plot were infected with the virus (as determined by laboratory examination for polyhedral bodies and by symptoms of the disease) within 4 days after the virus was applied. 
Unfortunately, examination of the larvae for the presence of the virus was not made at the time the experiment was begun. But since larvae in the control plot showed no evidence of infection until 8 days later, it is probably safe to assume that the same situation prevailed in the test plot. By the end of the experiment, the occurrence of a natural epizootic had raised the incidence of infection in the control plot to 82 per cent. Granting this, however, the figures still indicate that a full-fledged epizootic can be initiated artificially approximately 10 days ahead of a natural outbreak.

Plot 2. Test plot 2 and control plot 2 were each 25 by 360 feet in size. The test plot was treated with 1.5 gallons of virus suspension $(66,000,000$ polyhedra per milliliter). This experiment was initiated on September 23 and closed on September 30 when the field was cut for hay. On the last day of the experiment no actively moving larvae were found in the test plot. Most of those collected in the sweepings were dead, although a few moribund individuals were found. The average sweeping yielded 4 recently dead larvae. In the control plot, on the other hand, although there was a slight drop in the population (probably due to Apanteles parasitization), none of the larvae collected showed any evidence of the disease when examined in the laboratory.

The significance of this test lies in the fact that an epizootic was established in such a low population (never greater than 38 larvae per 10 sweeps). No active larvae were found in the test plot after 7 days. Such a negative finding probably does not represent true eradication of the pest in the plot, but it does indicate a very marked reduction in numbers.

Plot 3. Test plot 3 yielded data which, as in the preceding experiment, indicated that populations of relatively lower densities can be reduced by the polyhedrosis.

Plot 4. This experiment is perhaps the most significant of any of the four made in 1948. Not only was it concerned with the largest area of any of the 1948 tests, but also (in contrast to the situation that prevailed in plot 1), because of a prolonged period of egg-laying by the Colias females, young larvae were coming on continuously, making the test a very severe one.

The size of the fourth test plot was 225 by 750 feet. The control plot was of the same dimensions and ran parallel to the test plot but about 100 feet from it. Fifteen gallons of virus suspension $(50,000,000$ polyhedra per milliliter) were applied to the alfalfa of the test plot.

The number of larvae in the control plot rose from 4 per 10 sweeps to 253 per 10 sweeps in 14 days. In treated plots, the population rose to 60 per 10 sweeps by the sixth day, then rose slightly until on the fourteenth day the count was 98 per 10 sweeps. (During the incubation period of the disease the counts approximated each other rather closely.) As indicated above, this slight increase in numbers was undoubtedly caused by the continuous appearance of newly hatched larvae, since at no time did the number of fourth- and fifth-instar larvae in the test plot exceed 20 per 10 sweeps. Eventually, these new larvae must also have succumbed to the disease-many of them were already infected by the fourteenth day when the experiment was interrupted by the cutting of the field.

The outstanding thing indicated by this test is that in the fields treated with virus suspension, the caterpillar population was held below an economic 
level (usually considered as about 20 per 2 sweeps; Smith, 1949), whereas in the untreated control plot the population rose to over 350 , a level at which the insect began to cause marked economic damage as indicated by the amount of observable defoliation of the alfalfa plants.

Conclusions: The data which have just been presented concerning the four preliminary tests constitute significant promise, but not conclusive evidence that populations of the alfalfa caterpillar can be reliably controlled by the artificial distribution of the polyhedrosis virus. Plans for more extensive and complete tests were developed from the lessons learned during the 1948 field work. It was also necessary to work out the economies of the problem.

\section{FIELD TESTS}

Based on the experience gained in the 1948 field tests (Steinhaus and Thompson, 1949), several changes and modifications were adopted at the start of 1949 field work. All caterpillar population samples were standardized at 2 uniform sweeps of the sweeping net. In all one-acre plots, 5 samples were taken from each plot daily. In the larger-scale tests in which the virus was applied by airplane, 15 samples were taken daily from each treated and each control plot. The figures in the tables showing the results of the 1949 field tests are the average of the samples on the day indicated. Since the stage of growth of the caterpillar is important in regard to the amount of damage it can do to the alfalfa, and since it is also of great importance in the ApantelesColias relationship, the number of caterpillars in each instar was tabulated separately. The caterpillars usually do not cause much economic damage to vigorous stands of alfalfa until a large portion of the larval population is in the fourth and especially the fifth instar. In order to take advantage of control by the Apanteles parasite, it is necessary to ascertain the rate of parasitism before the virus is applied. The system used was that employed in the supervised control program developed by Ray F. Smith (1949) for coördinating the control by the parasite with chemical control of the caterpillar.

In September, 1948, 3 gallons of caterpillars dead or dying of polyhedrosis were collected from a field in which a natural epizootic was occurring. This virus material was blended in a Waring blender, and one gallon was stored in a refrigerator at $+2^{\circ} \mathrm{C}$., one gallon stored in a deep-freeze refrigerator at $-30^{\circ}$ C., and one gallon quick frozen in alcohol and dry ice at approximately $-70^{\circ} \mathrm{C}$., after which it was stored at $-30^{\circ} \mathrm{C}$. This material was tested at intervals throughout the winter of 1948 and spring of 1949. No decrease in virulence could be detected in virus stored under each of the three types of refrigeration. This virus material, stored in pint jars, was the source of supply for all of the 1949 field tests.

Since no hygro-thermograph was available during the summer tests, it was not possible to obtain a constant daily temperature and humidity record. Daily maximum and minimum temperatures were obtained from the records kept by the Miller-Lux Corporation in Los Banos, California.

Valuable assistance was afforded by Dr. Ray F. Smith and his group of entomologists who carried out the supervised control program for the West. side Alfalfa Pest Control Association. The selection of fields suitable for tests was based on population density reports provided by these entomologists. 


\section{Field Test 1}

This test was designed to determine if virus which had been stored in a frozen condition for nine months was still virulent when applied in the field. In addition the test afforded an opportunity to observe the effect of artificial dissemination of the virus in a field with a caterpillar population of economic importance.

The field selected for this test is located on the Redfern Ranch near Dos Palos, California. Alfalfa in the field was being grown for seed. The portion of the field containing the test plots was a rather poor stand of alfalfa, weedy and only about one foot high, although nearly mature. The ground was dry and cracked. There was marked variation in the Colias population which was considerably higher in the shorter stands of alfalfa. The control plot for each treatment was laid out 20 feet north (up-wind) from the treated plot. Population densities and environmental conditions were similar for each treatment and control, although there was some variation in the population density between treated plots.

The virus material used was collected in September, 1948, and kept frozen at $-30^{\circ}$ C. until July 12,1949 , when it was thawed out in preparation for the test. From this material, 10 gallons of virus suspension were prepared containing 50,000,000 polyhedra per milliliter. Two one-acre plots were each sprayed with five gallons of this suspension. The control for plot No. 1 was sprayed with five gallons of sterile water. The control for plot No. 2 was left untreated. Applications were made July 14, 1949, between nine and twelve o'clock in the morning. Population counts were made at this time of day on July 14, 19, 20, 21, and 22.

Conclusions: The results of this test, as shown in tables 2 and 3 and figures 1 and 2, show that the virus was still virulent at the time of application. An infection of 100 per cent was obtained in each treated plot while only a small percentage developed the disease in the control plots. A marked difference in the number of larvae in the treated and control plots appeared 6 days after application. Larvae taken from the treated plots 5 days after application showed symptoms of the disease and refused to eat when placed in individual cartons with small sprigs of alfalfa. This would indicate that no appreciable damage occurred to alfalfa in the treated plots later than 5 days after application. At the same time, in order to save the crop, it became necessary to treat the control plots with an insecticide.

\section{Field Test 2}

This test was designed to determine the virus (polyhedra) concentration necessary to insure infection of a field population of Colias larvae.

The field selected for test No. 2 is located on the Redfern Ranch near Oxalis, California. The alfalfa in the field was being grown for hay. It was a vigorous stand, uniform and about 18 inches high at the time of application, July 28, 1949. The Colias population in each test plot at the time of application is shown in tables 4 to 11 .

The virus material used was collected in September, 1948, quick-frozen in dry ice and alcohol, and then stored in a deep-freeze refrigerator $\left(-30^{\circ} \mathrm{C}.\right)$ 
until July 27, 1949, when it was removed and thawed for use in the virus suspensions prepared for this experiment.

Eight one-acre plots were treated in this experiment, and a control plot was established near to and up-wind from each plot. Plots 5 to 8 inclusive were replicates of plots 1 to 4 . There was a population gradient across the field, the population being highest in plots 4 and 8 and lowest in plots 1 and 5. Unfortunately, the locations of the plots were such that the replicates fell in areas of approximately the same population densities. Five gallons of virus suspension were applied to each one-acre plot treated.

The virus suspension applied to plots 1 and 5 contained 1,000,000 polyhedra per milliliter. The results are shown in tables 4 and 8 and figures 3 and 4 . The suspension applied to plots 2 and 6 contained 5,000,000 polyhedra per milliliter. The results are shown in tables 5 and 9 and figures 5 and 6 . Plots 3 and 7 were treated with a virus suspension containing $25,000,000$ polyhedra per milliliter. Results are shown in tables 6 and 10 and figures 7 and 8. Plots 4 and 8 were treated with a suspension containing 50,000,000 polyhedra per milliliter. The results are shown in tables 7 and 11 and figures 9 and 10 .

Conclusions: The results of this test indicate that even the greatest dilution of virus used, 1,000,000 polyhedra per milliliter, is sufficient to give "complete" infection of a field population of Colias larvae when applied at the rate of five gallons per acre. Apparently as a result of the high temperatures occurring during the period of this test, virus-caused mortality occurred in a shorter time than in any other test yet performed. Only 4-5 days were required to produce a marked difference between the populations of the treated and control plots.

\section{Field Test 3}

\section{Airplane Application No. 1}

The field selected for this experiment is located on the Hildebrand and Lindeman Ranch near Dos Palos, California. The alfalfa was being grown for hay. The alfalfa in the field was fairly uniform and of vigorous stand, about 18 inches high, except for a small area along the south edge of the field which was somewhat shorter. The Colias population preceding and at the time of application is shown in table 12.

The entire field of approximately 40 acres, with the exception of about two acres left as an untreated control, was treated with a virus suspension which was applied by airplane at the rate of approximately 5 gallons per acre. The suspension contained 5,000,000 polyhedra per milliliter. Approximately 5 milliliters of virus material per acre, or a total of 200 for the field, were used in preparing 200 gallons of virus suspension for the experiment.

The type of airplane used in these tests was a 450 horsepower N2S (Stearman) with a suspended-boom type of airplane sprayer. Agitation in the tank was provided by a recirculation pump. In applying the spray, the airplane flew approximately 6 feet above the alfalfa making swaths 45 feet in width (Fig. 12). The wind velocity was less than 5 miles per hour.

Daily counts of 15 samples each from the treated and control areas were made. A sample consisted of two standard sweeps of the sweeping net. The 
counts of average samples for each day of the test are shown in table 12. 'The results are also shown in graph form in figure 11.

Results: On the fourth day after application of the virus, considerable damage was done to the alfalfa by the caterpillar population. Some damage was also noticeable, in addition, on the fifth day, after which no additional damage was perceptible. The population of alfalfa caterpillars in the field reached a very high level during this test. Twenty unparasitized Colias larvae per 2 sweeps is considered by Smith (1949) to be potentially economic. During this test, the population rose to as high as 400 caterpillars per 2 sweeps.

Conclusions: The complete results of this test, as shown in table 12 and figure 11, demonstrate that high populations in an entire field can be greatly reduced by airplane applications of virus diluted to a concentration of $5,000,000$ polyhedra per milliliter. Poor timing in this particular test is indicated by the damage suffered by the crop on the fourth and fifth days after treatment (figure 13). It is probable that an application two days earlier would have prevented economic damage. This test also demonstrates that the caterpillars stop feeding about 2 days before they actually die. Approximately 7 gallons of virus material were recovered from the field on the seventh day after application, merely by sweeping up the dead and dying larvae with a net. This is about a hundredfold return on the half-pint used in the airplane application. This experiment emphasizes the extreme importance of proper timing of application. One day may mean the difference between economic loss and satisfactory control, especially when very high populations are involved.

\section{Field Test 4}

\section{Airplane Application No. 2}

This experiment was designed to determine if increased virus concentration would shorten the incubation period of the disease in the insect.

The field selected for this test is located on the Redfern Ranch, near Dos Palos, California, and is known as the Santa Fe Grade field. At the time of application, the field was under irrigation. The alfalfa was about 6 inches high in the eastern quarter of the field and about a foot high throughout the rest of the field. Colias oviposition had been heavy, especially in the lower stand, for a week before application. Cold weather and other unfavorable climatic factors, however, had greatly reduced the hatch and had caused heavy mortality in young first-instar larvae. These unfavorable conditions also prevailed during the first week after application when the weather turned warm again. Oviposition by adult female Colias had almost ceased by the end of the first week after application. Parasitism by Apanteles was high throughout the test, causing heavy mortality in young larvae. Irrigation of the field at the time of application caused rapid growth of the alfalfa, making uncontaminated oviposition sites available for the adult females.

The virus material used in this test was collected in September, 1949, and was stored at room temperature until used. Application was by airplane at the rate of five gallons per acre. Approximately twenty acres (plot A) were sprayed with a virus suspension containing 5,000,000 polyhedra per milliliter, 
and 20 acres (plot B) with a suspension containing 45,000,000 polyhedra per milliliter. An area of about forty acres was left as an untreated control.

Conclusions: Results of the experiment are shown in table 13 and figure 14. These data indicate that in cold weather the larvae treated with the heavier concentration exhibit polyhedra about one day earlier. These results may be compared with those of 1949 field test No. 2, conducted during warm weather, to show that increased concentration may be desirable in cold weather, but is of little, if any, advantage during warm weather. The results of this test also show that rapid growth of the alfalfa after application of the virus reduces the effectiveness of the treatment, especially if oviposition occurs during and after the new growth.

For a summarization of the 1949 field data showing comparison of total population counts, the reader is referred to table 14 .

\section{ECONOMICS OF VIRUS CONTROL}

\section{Supply}

It was found possible to build up an initial supply of virus material by two methods. The first technique used was to infect and rear, in the laboratory, healthy larvae brought in from the field. The second was to collect larvae dead and dying of the disease in the field. If an initial supply of virus is desired early in the season when natural epizootics are not likely to occur, the first method will be of value.

By loading a rearing tray, two feet wide by eight feet long, to capacity with field-collected larvae, it was found possible to produce one liter of virus material in seven days. One hour a day was required to feed and maintain the larvae during the incubation period. Three hours were required to take out the virus-killed larvae and place them in jars for storage. If it were desired to produce quantities of virus by this method, one man, by starting a new culture in a rearing tray each day, could produce a liter of virus daily, once production was started. This method requires a field source of caterpillars. It would be possible, however, to rear the larvae entirely by insectary methods, at an additional cost, if a field source were not available.

Once an initial supply of virus has been accumulated, the least expensive and easiest way of building up an additional supply is to spray a field containing a high population of caterpillars. By collecting the infected larvae with a sweeping net on the day before they can be expected to die of the disease, large quantities of the virus may be obtained. In one of the 1949 field tests where approximately one-half pint of virus material was used in the virus application, 7 gallons of virus material were recovered in 4 hours time on the sixth and seventh days after application.

Once a large supply has been built up, it may be maintained, or increased if desired, simply by collecting diseased larvae in the field at the proper time after application. While refrigeration does not appear to be necessary to preserve the virus in storage, it does prevent the action of putrefying bacteria and makes the material more pleasant to handle. The virus can be stored over winter in almost any manner desirable and will be ready for use the following year when populations of the caterpillar first appear. 


\section{Application}

As can be seen, the cost of producing the virus is not great. The cost of actual application is much the same as that of an application of a chemical insecticide. In the northern San Joaquin Valley, the present commercial charge for the airplane application of a spray at the rate of five gallons per acre is $\$ 1.50$ per acre. Ground application, while slower and more inconvenient, is considerably less expensive than that by airplane. Since most ground equipment is owned and used by the ranch owner, exact costs are not available. The cost of material plus application cost by airplane in a virus treatment should be less than that of most chemical insecticide applications. The cost of virus production may be reduced in the future by the use of more efficient methods.

While the successful use of a polyhedrosis as a means of controlling the alfalfa caterpillar may be expected in carefully planned and executed experiments, its general use by the alfalfa growers and commercial appliers of insecticides may entail some difficulties. The timing of application may be so critical that the average grower may not be in a position to determine when the virus should be used. At the time of application, the caterpillars have not yet begun to cause noticeable damage, and the grower may not even be aware of their presence. Once damage begins to show in the field, it is usually too late to use the virus disease as a practical means of control. The larvae will continue to feed for at least four days after application of the virus, and this period may be considerably prolonged by a period of cold weather. In fields with extremely high populations, it may be necessary to apply the virus before the caterpillars hatch from the egg. In this case, of course, the possibility of control by Apanteles parasites is forfeited. The most practical solution to the problem of properly timing large-scale applications of the virus appears to be through the use of trained entomologists as is done in supervised control programs. More extensive field testing of the efficacy of the virus is needed before any definite conclusions can be drawn as to the practicability of this agent as a means of economic control of the alfalfa caterpillar. 


\section{LITERATURE CITED}

BergoLd, G.

1942. Polyederfreie Insektenzuchten. Die Naturwis. $30: 422-23$.

LOUNSBURY, C. P.

1913. Caterpillar wilt disease. Agr. J. Union S. Africa 5:448-52.

SMITH, R. F.

1949. Manual of supervised control (revised). Division of Entomology and Parasitology, University of California. Mimeo. 28 p.

Steinhaus, E. A.

1945. Insect pathology and biological control. Jour. Econ. Ent. 38:591-96.

1948. Polyhedrosis ("wilt disease") of the alfalfa caterpillar. Jour. Econ. Ent. 41 : 859-65.

1949a. Principles of insect pathology. 757 p. MeGraw-Hill Book Co. New York, N.Y.

1949b. Nomenclature and classification of insect viruses. Bact. Rev. 13:203-23.

Steinhaus, E. A., and C. G. Thompson.

1949. Preliminary field tests using a polyhedrosis virus in the control of the alfalfa caterpillar. Jour. Econ. Ent. 42:301-5.

The authors wish to thank Dr. Ray F. Smith of the Division of Entomology and Parasitology for his helpful suggestions and advice relating not only to the work in general but in the preparation of this manuscript as well.

\section{FIGURES AND TABLES}

TABLE 1

Results of Egg Sterilization Experiments Showing Treatment, Exposure, AND VIRUS INFECTION

\begin{tabular}{|c|c|c|c|c|c|c|c|c|}
\hline \multirow{2}{*}{ Treatment } & \multirow{2}{*}{$\begin{array}{l}\text { Time eggs } \\
\text { exposed }\end{array}$} & \multirow{2}{*}{$\begin{array}{l}\text { No. of eggs } \\
\text { exposed }\end{array}$} & \multicolumn{2}{|c|}{$\underset{\text { hatched }}{\text { Eggs }}$} & \multicolumn{2}{|c|}{$\begin{array}{l}\text { Larvae died } \\
\text { of virus }\end{array}$} & \multicolumn{2}{|c|}{$\begin{array}{l}\text { Disease-free } \\
\text { larvae }\end{array}$} \\
\hline & & & No. & Per cent & No. & Per cent & No. & Per cent \\
\hline 15 per cent trichloracetic acid. & $60 \mathrm{~min}$. & 100 & 62 & 62 & 21 & 34 & 41 & 66 \\
\hline 30 per cent trichloracetic acid. & 30 min. & 100 & 71 & 71 & 23 & 32 & 48 & 68 \\
\hline \multirow[t]{3}{*}{10 per cent hydrochloric acid. } & 5 min. & 100 & 81 & 81 & 28 & 35 & 53 & 65 \\
\hline & $10 \mathrm{~min}$. & 100 & 79 & 79 & 24 & 30 & 55 & 70 \\
\hline & 30 min. & 100 & 58 & 58 & 16 & 28 & 42 & 72 \\
\hline \multirow[t]{2}{*}{70 per cent ethyl alcohol. } & 15 min. & 100 & 83 & 83 & 29 & 35 & 54 & 65 \\
\hline & $30 \mathrm{~min}$. & 100 & 77 & 77 & 25 & 32 & 52 & 68 \\
\hline 10 per cent copper sulfate. & $30 \mathrm{~min}$. & 100 & 84 & 84 & 30 & 36 & 54 & 64 \\
\hline \multirow{6}{*}{10 per cent formaldehyde (by weight). } & $15 \mathrm{~min}$. & 100 & 86 & 86 & 21 & 24 & 65 & 76 \\
\hline & $30 \mathrm{~min}$. & 100 & 81 & 81 & 15 & 19 & 66 & 81 \\
\hline & $45 \mathrm{~min}$. & 100 & 74 & 74 & 5 & 7 & 69 & 93 \\
\hline & $60 \mathrm{~min}$. & 250 & 170 & 68 & 4 & 2.4 & 166 & 97.6 \\
\hline & $90 \mathrm{~min}$. & 250 & 162 & 65 & 3 & 1.9 & 159 & 98.1 \\
\hline & $120 \mathrm{~min}$. & 250 & 147 & 59 & 3 & 2.0 & 144 & 98 \\
\hline \multirow[t]{3}{*}{5 per cent potassium hydroxide.... } & 5 min. & 100 & 76 & 76 & 25 & 33 & 51 & 67 \\
\hline & 10 min. & 100 & 54 & 54 & 16 & 29 & 40 & 71 \\
\hline & $30 \mathrm{~min}$. & 100 & 28 & 28 & 7 & 25 & 21 & 75 \\
\hline \multirow[t]{3}{*}{ Ultraviolet light at 15 inches } & $60 \mathrm{~min}$. & 100 & 91 & 91 & 30 & 33 & 61 & 67 \\
\hline & $120 \mathrm{~min}$. & 100 & 89 & 89 & 28 & 31 & 61 & 69 \\
\hline & $180 \mathrm{~min}$. & 100 & 86 & 86 & 29 & 35 & 57 & 65 \\
\hline Control (untreated).. & $\ldots \ldots$ & 100 & 94 & 94 & 33 & 35 & 61 & 65 \\
\hline
\end{tabular}




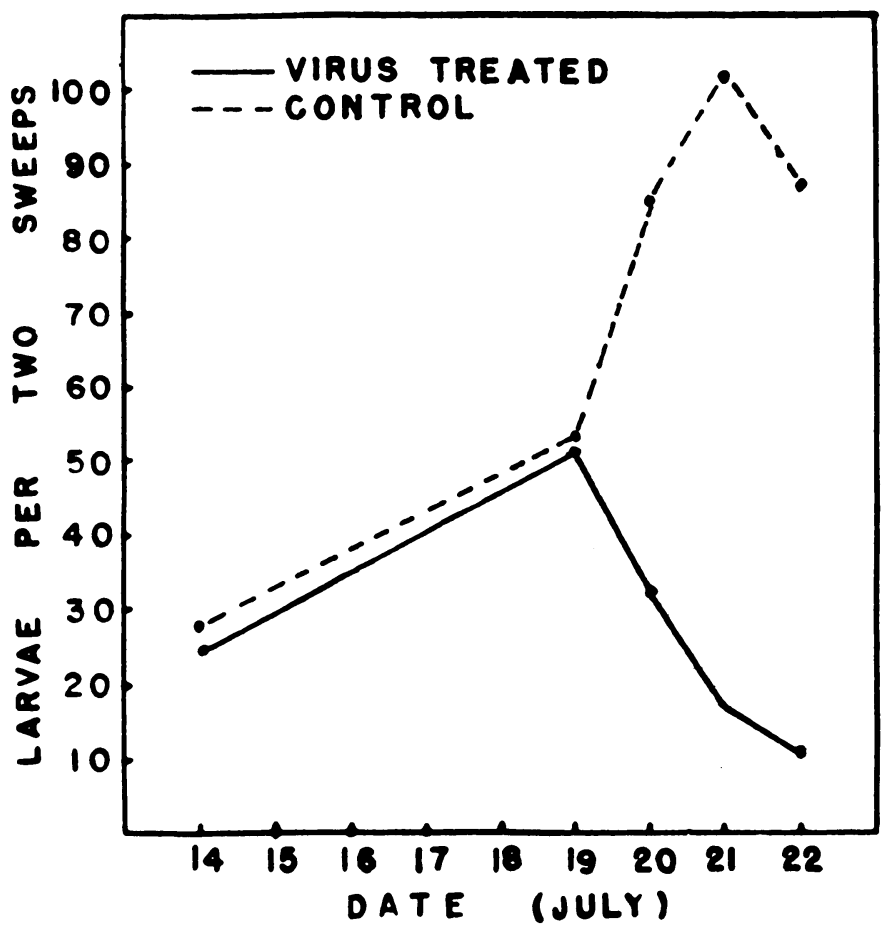

Fig. 1. The number of larvae per two sweeps in the treated and untreated (control) portions of 1949 field test 1 , plot 1.

TABLE 2

Results of 1949 Field Test 1, Plot 1, Showing Number (Average of Two-Sweep Samples) and Instar of Colias Larvae in Treated and Untreated Plots and the Percentage of Larvaei INFEcted With Virus. Virus APPLIED JULY 14, 1949

\begin{tabular}{|c|c|c|c|c|c|c|c|c|c|c|}
\hline \multirow{2}{*}{ Treatment } & \multirow{2}{*}{ Date } & \multicolumn{2}{|c|}{ Daily temperature } & \multicolumn{4}{|c|}{ Instar } & \multirow{2}{*}{$\begin{array}{l}\text { Total all } \\
\text { instars }\end{array}$} & \multirow{2}{*}{$\begin{array}{c}\text { Per cent } \\
\text { ISRP1 }\end{array}$} & \multirow{2}{*}{$\begin{array}{c}\text { Per cent } \\
\text { with } \\
\text { poly- } \\
\text { hedra }\end{array}$} \\
\hline & & Min. & Max. & $1-2$ & 3 & 4 & 5 & & & \\
\hline Treated. & $7-14$ & $\begin{array}{c}{ }^{\circ} \mathrm{F} \\
59\end{array}$ & ${ }_{103}^{\circ \mathrm{F}}$ & 7 & 9 & 6 & 3 & 25 & $\ldots$ & 0 \\
\hline Control.. & $7-14$ & 59 & 103 & 6 & 10 & 8 & 4 & 28 & .. & 0 \\
\hline Treated. & $7-19$ & 57 & 105 & 11 & 15 & 12 & 14 & 52 & 5 & 100 \\
\hline Control. . & $7-19$ & 57 & 105 & 13 & 18 & 12 & 10 & 53 & 5 & 10 \\
\hline Treated. . & $7-20$ & 51 & 96 & 7 & 16 & 6 & 6 & 35 & 5 & 100 \\
\hline Control... & $7-20$ & 51 & 96 & 13 & 46 & 15 & 10 & 84 & 5 & 15 \\
\hline Treated.. & $7-21$ & 62 & 96 & 5 & 11 & 3 & 2 & 21 & 30 & 90 \\
\hline Control.......... & $7-21$ & 62 & 96 & 21 & 49 & 24 & 8 & 102 & 30 & 20 \\
\hline Treated. & $7-22$ & 58 & 94 & 3 & 7 & 1 & 1 & 12 & 15 & 100 \\
\hline Control. . & $7-22$ & 58 & 94 & 14 & 30 & 24 & 18 & 86 & 40 & 15 \\
\hline
\end{tabular}

1 Per cent in the size range (late second, third, and early fourth instars) parasitized. (See Smith, 1949.) 


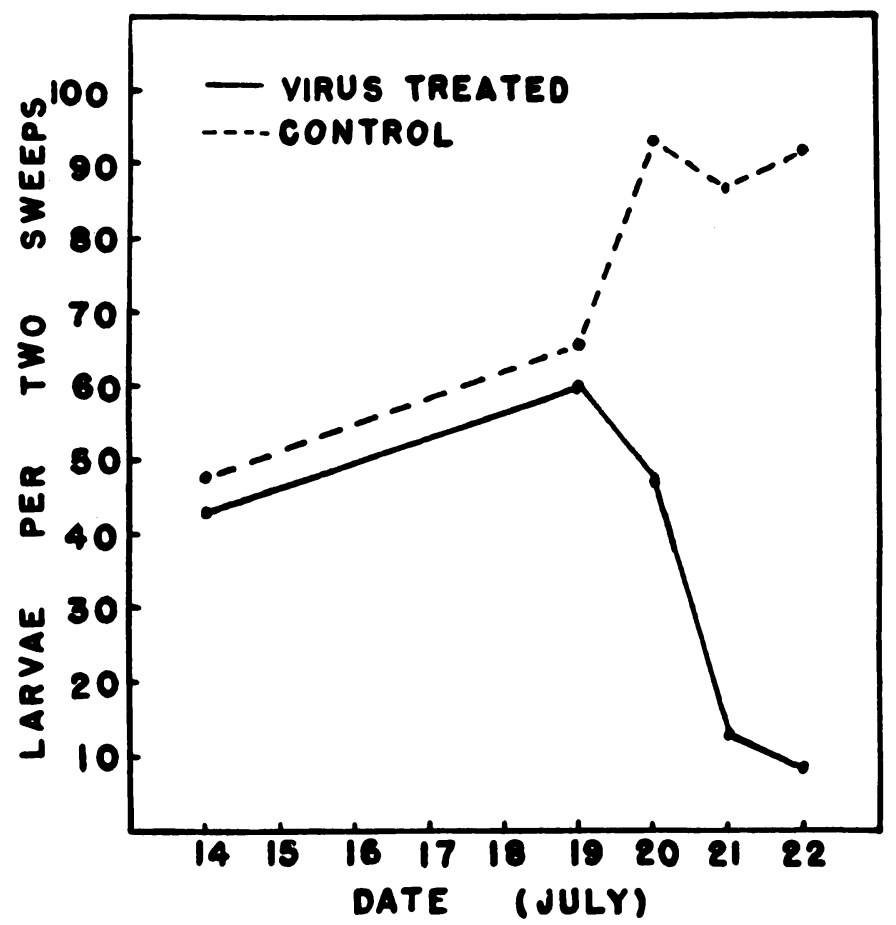

Fig. 2. The number of larvae per two sweeps in the treated and untreated (control) portions of 1949 field test 1 , plot 2 .

\section{TABLE 3}

Resutts of 1949 Fibld Test 1, Plot 2, Showing Number (Average of Two-Sweep Samples) and Instar of Colias Larvae in Treatted and Untreated Plots aNd THE PERCENTAge of LaRVae IN FECTED With Virus. VIRUS APPLIED JULy 14, 1949

\begin{tabular}{|c|c|c|c|c|c|c|c|c|c|c|}
\hline \multirow{2}{*}{ Treatment } & \multirow{2}{*}{ Date } & \multicolumn{2}{|c|}{ Daily temperature } & \multicolumn{4}{|c|}{ Instar } & \multirow{2}{*}{$\begin{array}{l}\text { Total all } \\
\text { instars }\end{array}$} & \multirow{2}{*}{$\begin{array}{l}\text { Per cent } \\
\text { ISRP }\end{array}$} & \multirow{2}{*}{$\begin{array}{c}\text { Per cent } \\
\text { with } \\
\text { poly- } \\
\text { hedra }\end{array}$} \\
\hline & & Min. & Max. & $1-2$ & 3 & 4 & 5 & & & \\
\hline & & ${ }^{\circ} \mathrm{F}$ & ${ }^{\circ} \mathrm{F}$ & & & & & & & \\
\hline Treated. & $7-14$ & 59 & 103 & 11 & 18 & 9 & 5 & 43 & .. & 0 \\
\hline Control.. & $7-14$ & 59 & 103 & 13 & 21 & 8 & 7 & 48 & .. & 0 \\
\hline Treated. & $7-19$ & 57 & 105 & 14 & 22 & 12 & 12 & 60 & 5 & 100 \\
\hline Control.......... & $7-19$ & 57 & 105 & 15 & 27 & 16 & 8 & 66 & 5 & 0 \\
\hline Treated...... & $7-20$ & 51 & 96 & 7 & 24 & 8 & 8 & 47 & 8 & 95 \\
\hline Control....... & $7-20$ & 51 & 96 & 20 & 50 & 17 & 9 & 93 & 10 & 5 \\
\hline Treated. . & $7-21$ & 62 & 96 & 4 & 9 & 0 & 0 & 13 & 20 & 100 \\
\hline Control. & $7-21$ & 62 & 96 & 10 & 39 & 18 & 10 & 77 & 30 & 10 \\
\hline Treated. & $7-22$ & 58 & 94 & 3 & 5 & 1 & 1 & 9 & 25 & 100 \\
\hline Control. . & $7-22$ & 58 & 94 & 12 & 29 & 22 & 18 & 81 & 40 & 10 \\
\hline
\end{tabular}




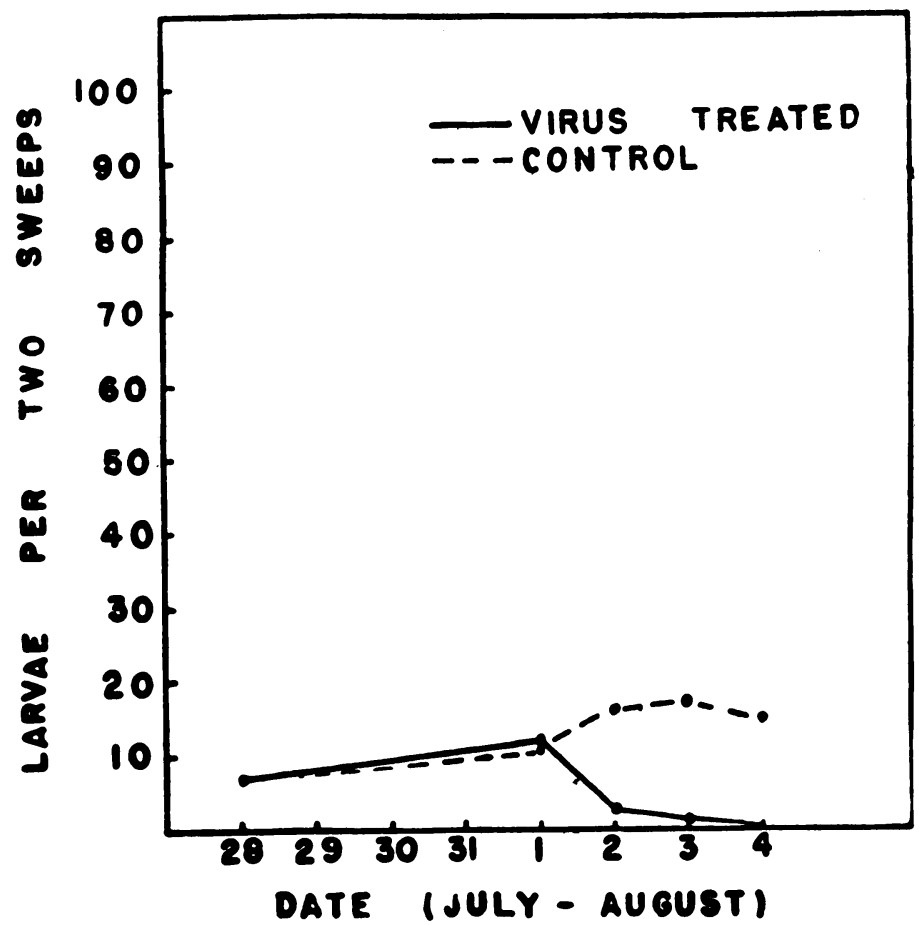

Fig. 3. The number of larvae per two sweeps in the treated and untreated (control) portions of 1949 field test 2, plot 1 . Concentration of virus suspension: $1,000,000$ polyhedra per milliliter.

\section{TABLE 4}

Results of 1949 Field Test 2, Plot 1, Showing Number (Average of Two-Sweep Samples) and Instar of Colias Larvae in Treated and Untreated Plots and the Percentage of Larvae Infected with Virus. Virus A pPlied July 28, 1949. Virus Concentration 1,000,000

POLYHEDRA PER ML.

\begin{tabular}{|c|c|c|c|c|c|c|c|c|c|c|}
\hline \multirow{2}{*}{ Treatment } & \multirow{2}{*}{ Date } & \multicolumn{2}{|c|}{ Daily temperature } & \multicolumn{4}{|c|}{ Instar } & \multirow{2}{*}{$\begin{array}{c}\text { Total all } \\
\text { instars }\end{array}$} & \multirow{2}{*}{$\begin{array}{l}\text { Per cent } \\
\text { ISRP }\end{array}$} & \multirow{2}{*}{$\begin{array}{c}\text { Per cent } \\
\text { with } \\
\text { poly- } \\
\text { hedra }\end{array}$} \\
\hline & & Min. & Max. & 1-2 & 3 & 4 & 5 & & & \\
\hline Treated & $7-28$ & ${ }^{\circ} \mathrm{F}$ & ${ }^{\circ} \mathrm{F}$ & 4 & 3 & 1 & 1 & 9 & 10 & 0 \\
\hline Control.. & $7-28$ & 56 & $\begin{array}{l}94 \\
94\end{array}$ & $\begin{array}{l}\mathbf{4} \\
2\end{array}$ & $\begin{array}{l}0 \\
5\end{array}$ & $\begin{array}{l}1 \\
1\end{array}$ & $\begin{array}{l}1 \\
2\end{array}$ & $\begin{array}{r}9 \\
10\end{array}$ & $\begin{array}{l}10 \\
10\end{array}$ & 0 \\
\hline Treated. & $8-1$ & 63 & 101 & 2 & 5 & 1 & 4 & 12 & 50 & 100 \\
\hline Control. . & $8-1$ & 63 & 101 & 1 & 4 & 3 & 3 & 11 & 50 & 0 \\
\hline Treated.... & $8-2$ & 59 & 103 & 0 & 0 & 1 & 2 & 3 & 40 & 100 \\
\hline Control.... & $8-2$ & 59 & 103 & 0 & 6 & 3 & 7 & 16 & 50 & 0 \\
\hline Treated. & $8-3$ & 56 & 105 & 0 & 0 & 1 & 0 & 1 & .. & 100 \\
\hline Control. & $8-3$ & 56 & 105 & 0 & 5 & 4 & 8 & 17 & 50 & 0 \\
\hline Treated. & $8-4$ & 60 & 100 & 0 & 0 & 0 & 0 & 0 & .. & .. \\
\hline Control. & $8-4$ & 60 & 100 & 0 & 4 & 6 & 5 & 15 & 60 & 0 \\
\hline
\end{tabular}




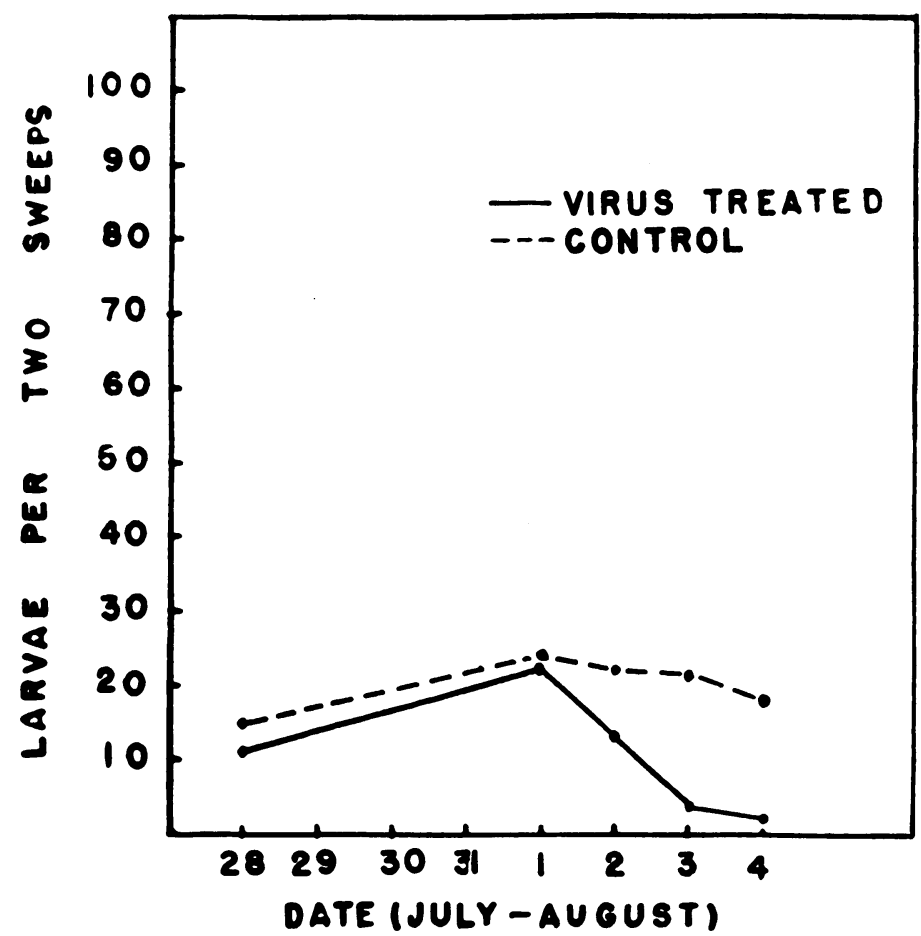

Fig. 4. The number of larvae per two sweeps in the treated and untreated (control) portions of 1949 field test 2, plot 2. Concentration of virus suspension: 5,000,000 polyhedra per milliliter.

\section{TABLE 5}

Results of 1949 Field Test 2, Plot 2, Showing Number (A verage of Two-Sweep Samples) and Instar of Colias Larvae in Treated and Untreated Plots and the Percentage of Larvae Infected with Virus. Virus ApPlied July 28, 1949. Virus Concentration 5,000,000 PolyhedRa PER ML.

\begin{tabular}{|c|c|c|c|c|c|c|c|c|c|c|}
\hline \multirow{2}{*}{ Treatment } & \multirow{2}{*}{ Date } & \multicolumn{2}{|c|}{ Daily temperature } & \multicolumn{4}{|c|}{ Instar } & \multirow{2}{*}{$\begin{array}{l}\text { Total all } \\
\text { instars }\end{array}$} & \multirow{2}{*}{$\begin{array}{l}\text { Per cent } \\
\text { ISRP }\end{array}$} & \multirow{2}{*}{$\begin{array}{l}\text { Per cent } \\
\text { with } \\
\text { poly- } \\
\text { hedra }\end{array}$} \\
\hline & & Min. & Max. & $1-2$ & 3 & 4 & 5 & & & \\
\hline Treated... & $7-28$ & $\begin{array}{c}{ }^{\circ} \mathrm{F} \\
56\end{array}$ & $\begin{array}{l}{ }^{\circ} \mathrm{F} \\
94\end{array}$ & 3 & 5 & 2 & 1 & 11 & 10 & 0 \\
\hline Control. . & $7-28$ & 56 & 94 & 5 & 6 & 3 & 1 & 15 & 10 & 0 \\
\hline Treated. . & $8-1$ & 63 & 101 & 0 & 11 & 4 & 7 & 22 & 32 & 100 . \\
\hline Control.. & $8-1$ & 63 & 101 & 1 & 13 & 5 & 5 & 24 & 40 & 0 \\
\hline Treated. & $8-2$ & 59 & 103 & 1 & 3 & 1 & 8 & 13 & 70 & 100 \\
\hline Control. & $8-2$ & 59 & 103 & 2 & 11 & 3 & 9 & 25 & 80 & 0 \\
\hline Treated. & $8-3$ & 56 & 105 & 1 & 2 & 1 & 0 & 4 & 80 & 100 \\
\hline Control & $8-3$ & 56 & 105 & 1 & 10 & 4 & 6 & 21 & 80 & 0 \\
\hline Treated. & $8-4$ & 60 & 100 & 0 & 1 & 1 & 0 & 2 & & 100 \\
\hline Control. & $8-4$ & 60 & 100 & 0 & 7 & 4 & 7 & 18 & 70 & 0 \\
\hline
\end{tabular}




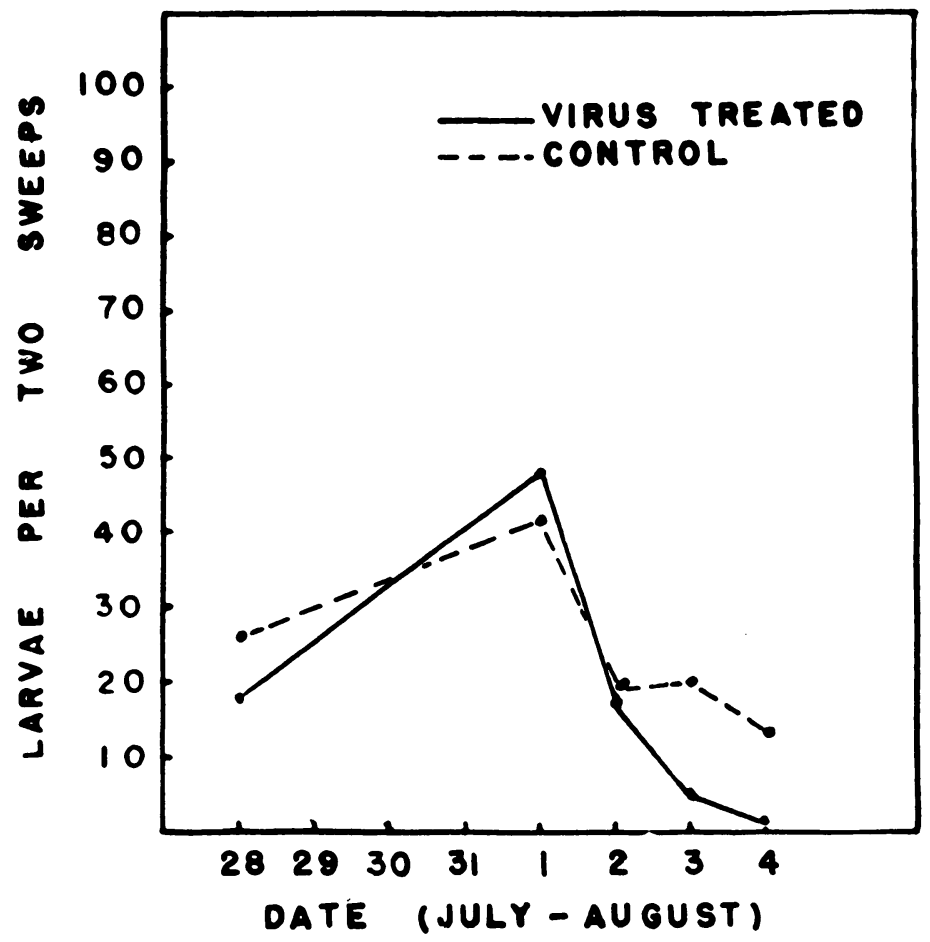

Fig. 5. The number of larvae per two sweeps in the treated and untreated (control) portions of 1949 field test 2, plot 3. Concentration of virus suspension : $25,000,000$ polyhedra per milliliter.

\section{TABLE 6}

Results of 1949 Field Test 2, Plot 3, Showing Number (Average of Two-Sweep Samples) and Instar of Colias Larvae in Treated and Untreated Plots and the Percentage of Larvae Infected with Virus. Virus Applied July 28, 1949. Virus Concentration 25,000,000 Polyhedra PER ML.

\begin{tabular}{|c|c|c|c|c|c|c|c|c|c|c|}
\hline \multirow{2}{*}{ Treatment } & \multirow{2}{*}{ Date } & \multicolumn{2}{|c|}{ Daily temperature } & \multicolumn{4}{|c|}{ Instar } & \multirow{2}{*}{$\begin{array}{l}\text { Total all } \\
\text { instars }\end{array}$} & \multirow{2}{*}{$\begin{array}{l}\text { Per cent } \\
\text { ISRP }\end{array}$} & \multirow{2}{*}{$\begin{array}{c}\text { Per cent } \\
\text { with } \\
\text { poly- } \\
\text { hedra }\end{array}$} \\
\hline & & Min. & Max. & $1-2$ & 3 & 4 & 5 & & & \\
\hline Treated & $7-28$ & $\begin{array}{c}\circ \mathrm{F} \\
56\end{array}$ & $\begin{array}{l}\circ \mathrm{F} \\
94\end{array}$ & 2 & 8 & 6 & 2 & 18 & 20 & 0 \\
\hline Control.. & $7-28$ & 56 & 94 & 3 & 12 & 10 & 1 & 26 & 20 & 0 \\
\hline Treated. & $8-1$ & 63 & 101 & 2 & 18 & 8 & 20 & 48 & 60 & 100 \\
\hline Control... & $8-1$ & 63 & 101 & 2 & 16 & 6 & 17 & 41 & 60 & 0 \\
\hline Treated........ & $8-2$ & 59 & 103 & 1 & 5 & 5 & 6 & 17 & 80 & 100 \\
\hline Control... & $8-2$ & 59 & 103 & 0 & 3 & 3 & 13 & 19 & 80 & 0 \\
\hline Treated. . & $8-3$ & 56 & 105 & 0 & 2 & 1 & 2 & 5 & 70 & 100 \\
\hline Control. . & $8-3$ & 56 & 105 & 1 & 5 & 4 & 10 & 20 & 80 & 0 \\
\hline Treated. & $8-4$ & 60 & 100 & 0 & 1 & 0 & 0 & 1 & 60 & 100 \\
\hline Control. & $8-4$ & 60 & 100 & 0 & 3 & 2 & 8 & 13 & 80 & 10 \\
\hline
\end{tabular}




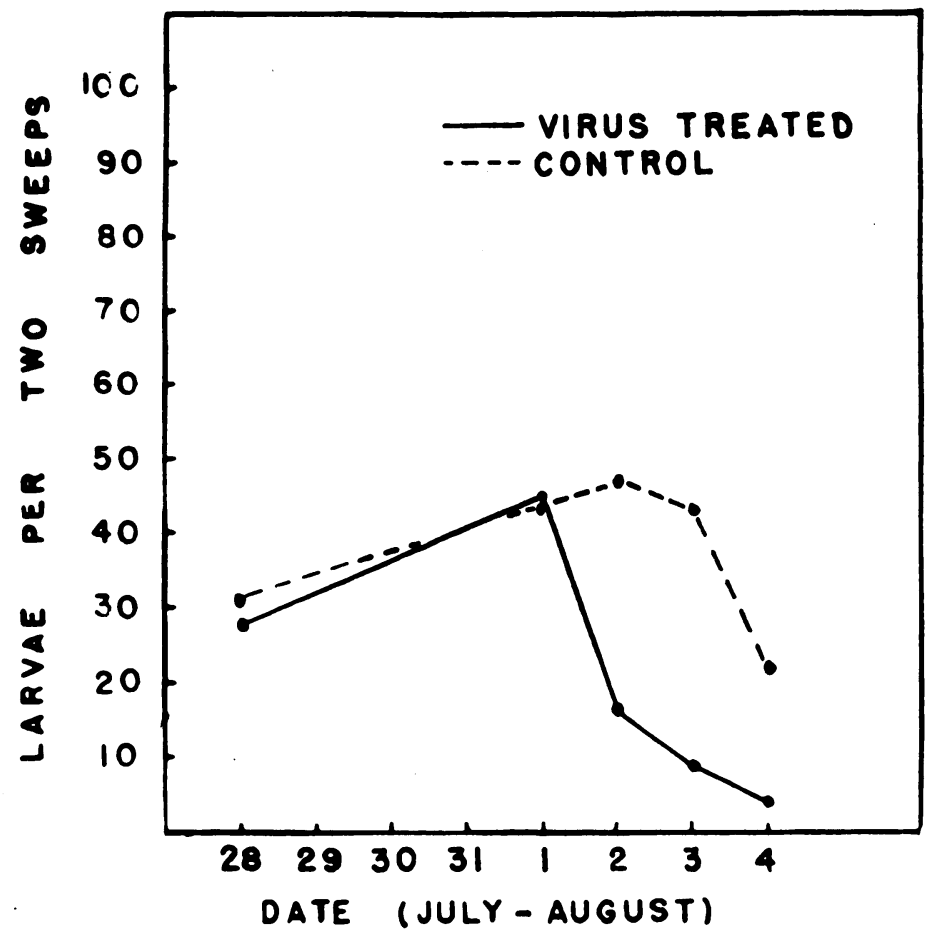

Fig. 6. The number of larvae per two sweeps in the treated and untreated (control) portions of 1949 field test 2 , plot 4 . Concentration of virus suspension: $50,000,000$ polyhedra per milliliter.

\section{TABLE 7}

Results of 1949 Field Test 2, Plot 4, Showing Number (Average of Two-Sweep Samples) and Instar of Colias Larvae in Treated and Untreated Plots and the Percentage of Larvae Intected with Virus. Virus Applied JUly 28, 1949. Virus ConCentration 50,000,000 POLYHEDRA PER ML.

\begin{tabular}{|c|c|c|c|c|c|c|c|c|c|c|}
\hline \multirow{2}{*}{ Treatment } & \multirow{2}{*}{ Date } & \multicolumn{2}{|c|}{ Daily temperature } & \multicolumn{4}{|c|}{ Instar } & \multirow{2}{*}{$\begin{array}{c}\text { Total all } \\
\text { instars }\end{array}$} & \multirow{2}{*}{$\begin{array}{l}\text { Per cent } \\
\text { ISRP }\end{array}$} & \multirow{2}{*}{$\begin{array}{c}\text { Per cent } \\
\text { with } \\
\text { poly- } \\
\text { hedra }\end{array}$} \\
\hline & & Min. & Max. & $1-2$ & 3 & 4 & 5 & & & \\
\hline Treated. & $7-28$ & $\begin{array}{l}{ }^{\circ} \mathrm{F} \\
56\end{array}$ & $\begin{array}{l}\circ \mathrm{F} \\
94\end{array}$ & 6 & 9 & 5 & 8 & 28 & 10 & 0 \\
\hline Control... & $7-28$ & 56 & 94 & 8 & 8 & 9 & 6 & 31 & 10 & 0 \\
\hline Treated. & $8-1$ & 63 & 101 & 2 & 12 & 12 & 19 & 45 & 50 & 100 \\
\hline Control. & $8-1$ & 63 & 101 & 0 & 13 & 10 & 21 & 44 & 50 & 0 \\
\hline Treated. . & 8-2 & 59 & 103 & 0 & 10 & 2 & 4 & 16 & 70 & 100 \\
\hline Control.. & $8-2$ & 59 & 103 & 0 & 21 & 10 & 16 & 47 & 70 & 0 \\
\hline Treated... & $8-3$ & 56 & 105 & 0 & 5 & 3 & 1 & 9 & 40 & 100 \\
\hline Control. & $8-3$ & 56 & 105 & 0 & 15 & 11 & 17 & 43 & 80 & 0 \\
\hline Treated. & $8-4$ & 60 & 100 & 0 & 3 & 1 & 0 & 4 & 50 & 100 \\
\hline Control.. & 84 & 60 & 100 & 0 & 11 & 7 & 9 & 27 & 80 & 0 \\
\hline
\end{tabular}




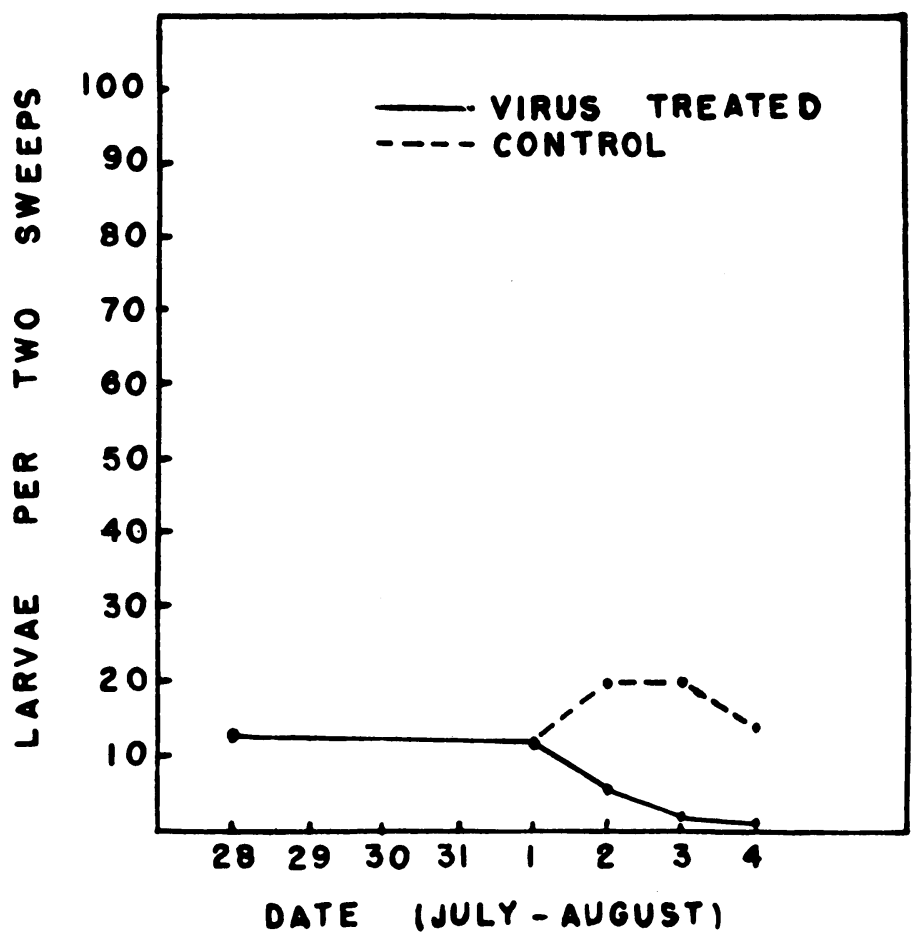

Fig. 7. The number of larvae per two sweeps in the treated and untreated (control) portions of 1949 field test 2, plot 5. Concentration of virus suspension: $1,000,000$ polyhedra per milliliter.

\section{TABLE 8}

Resdits of 1949 Field Test 2, Plot 5, Showing Number (Average of Two-Sweep

Samples) and Instar of Colias Larvae in Treated and Untreated Plots and

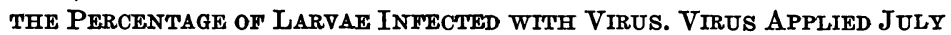
28, 1949. Virus CoNCentration 1,000,000 PolyhedRA PER ML.

\begin{tabular}{|c|c|c|c|c|c|c|c|c|c|c|}
\hline \multirow{2}{*}{ Treatment } & \multirow{2}{*}{ Date } & \multicolumn{2}{|c|}{ Daily temperature } & \multicolumn{4}{|c|}{ Instar } & \multirow{2}{*}{$\begin{array}{c}\text { Total all } \\
\text { instars }\end{array}$} & \multirow{2}{*}{$\begin{array}{c}\text { Per cent } \\
\text { ISRP }\end{array}$} & \multirow{2}{*}{$\begin{array}{c}\text { Per cent } \\
\text { with } \\
\text { poly- } \\
\text { hedra }\end{array}$} \\
\hline & & Min. & Max. & $1-2$ & 3 & 4 & 5 & & & \\
\hline & & ${ }^{\circ} \mathrm{F}$ & $\circ \mathrm{F}$ & & & & & & & \\
\hline Treated. & $7-28$ & 56 & 94 & 5 & 4 & 3 & 1 & 13 & 10 & 0 \\
\hline Control. & $7-28$ & 56 & 94 & 6 & 3 & 2 & 2 & 13 & 10 & 0 \\
\hline Treated. & $8-1$ & 63 & 101 & 1 & 4 & 2 & 5 & 12 & 50 & 100 \\
\hline Control.. & $8-1$ & 63 & 101 & 1 & 6 & 1 & 4 & 12 & 50 & 0 \\
\hline Treated.. & 8-2 & 59 & 103 & 0 & 1 & 2 & 3 & 6 & 50 & 100 \\
\hline Control.. & $8-2$ & 59 & 103 & 0 & 8 & 4 & 8 & 20 & 70 & 0 \\
\hline Treated....... & $8-3$ & 56 & 105 & 0 & 1 & 1 & 0 & 2 & 50 & 100 \\
\hline Control... & $8-3$ & 56 & 105 & 0 & 5 & 6 & 9 & 20 & 70 & 0 \\
\hline Treated. . & $8-4$ & 60 & 100 & 0 & 1 & 0 & 0 & 1 & 50 & 100 \\
\hline Control... & $8-4$ & 60 & 100 & 0 & 3 & 4 & 7 & 14 & 60 & 0 \\
\hline
\end{tabular}




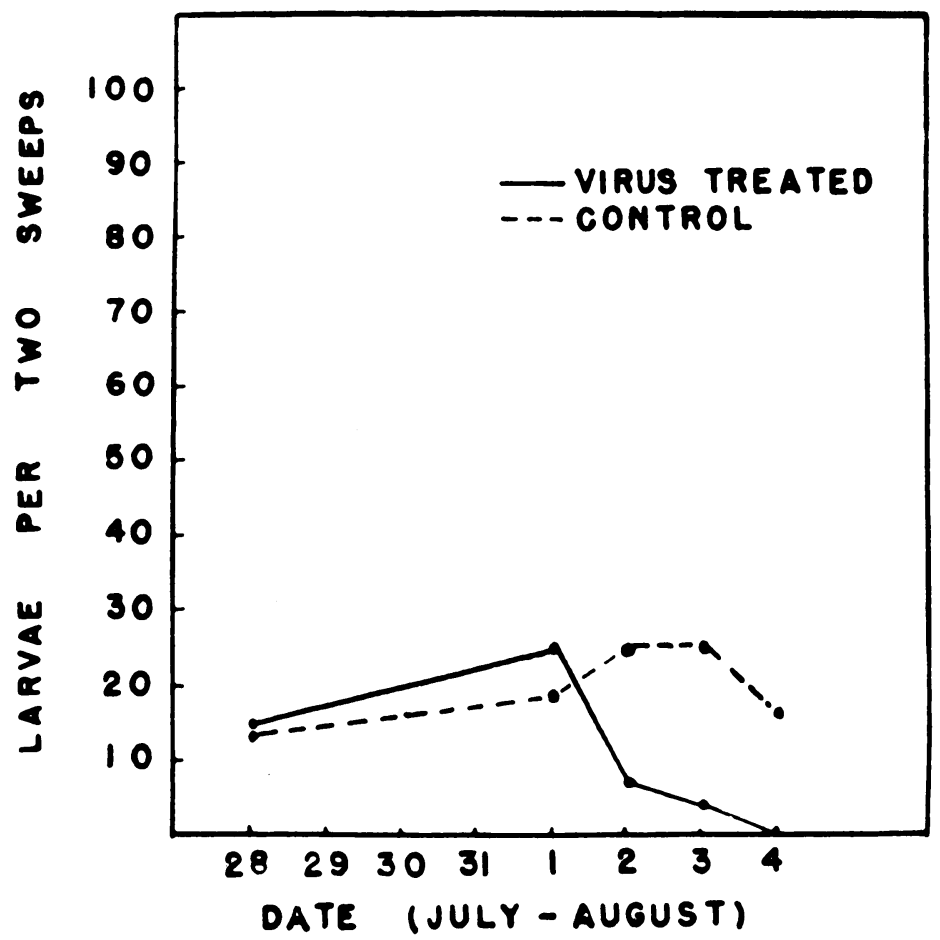

Fig. 8. The number of larvae per two sweeps in the treated and untreated (control) portions of 1949 field test 2 , plot 6 . Concentration of virus suspension: 5,000,000 polyhedra per milliliter.

TABLE 9

Results of 1949 Field Test 2, Plot 6, Showing Number (Average of Two-Sweep Samples) and Instar of Colias Larvae in Treated and Untreated Plots and the Percentage of Larvae Infiected with Virus. Virus Applied July 28, 1949. VirUs CONCENTRATION 5,000,000 POLYHEDRA PER ML.

\begin{tabular}{|c|c|c|c|c|c|c|c|c|c|c|}
\hline \multirow{2}{*}{ Treatment } & \multirow{2}{*}{ Date } & \multicolumn{2}{|c|}{ Daily temperature } & \multicolumn{4}{|c|}{ Instar } & \multirow{2}{*}{$\begin{array}{c}\text { Total all } \\
\text { instars }\end{array}$} & \multirow{2}{*}{$\begin{array}{l}\text { Per cent } \\
\text { ISRP }\end{array}$} & \multirow{2}{*}{$\begin{array}{c}\text { Per cen } \\
\text { with } \\
\text { poly- } \\
\text { hedra }\end{array}$} \\
\hline & & Min. & Max. & $1-2$ & 3 & 4 & 5 & & & \\
\hline & & ${ }^{\circ} \mathrm{F}$ & ${ }^{\circ} \mathrm{F}$ & & & & & & & 0 \\
\hline $\begin{array}{l}\text { Treated.. } \\
\text { Control... }\end{array}$ & $\begin{array}{l}7-28 \\
7-28\end{array}$ & $\begin{array}{l}56 \\
56\end{array}$ & $\begin{array}{l}94 \\
94\end{array}$ & $\begin{array}{l}6 \\
7\end{array}$ & $\begin{array}{l}3 \\
2\end{array}$ & $\begin{array}{l}5 \\
4\end{array}$ & $\begin{array}{l}1 \\
1\end{array}$ & $\begin{array}{l}15 \\
14\end{array}$ & $\begin{array}{l}20 \\
15\end{array}$ & $\begin{array}{l}0 \\
0\end{array}$ \\
\hline Treated. . & $8-1$ & 63 & 101 & 1 & 10 & 4 & 10 & 25 & 60 & 100 \\
\hline Control........ & $8-1$ & 63 & 101 & 0 & 6 & 4 & 9 & 19 & 50 & 0 \\
\hline Treated. & $8-2$ & 59 & 103 & 0 & 2 & 1 & 4 & 7 & 70 & 100 \\
\hline Control. & $8-2$ & 59 & 103 & 1 & 12 & 4 & 8 & 25 & 70 & 0 \\
\hline Treated. & $8-3$ & 56 & 105 & 0 & 2 & 1 & 1 & 4 & 50 & 100 \\
\hline Control. . & $8-3$ & 56 & 105 & 0 & 8 & 7 & 10 & 25 & 70 & $\mathbf{0}$ \\
\hline Treated. & $8-4$ & 60 & 100 & 0 & 0 & 0 & 0 & 0 & . & 100 \\
\hline Control. & $8-4$ & 60 & 100 & 0 & 4 & 4 & 8 & 16 & 70 & 0 \\
\hline
\end{tabular}




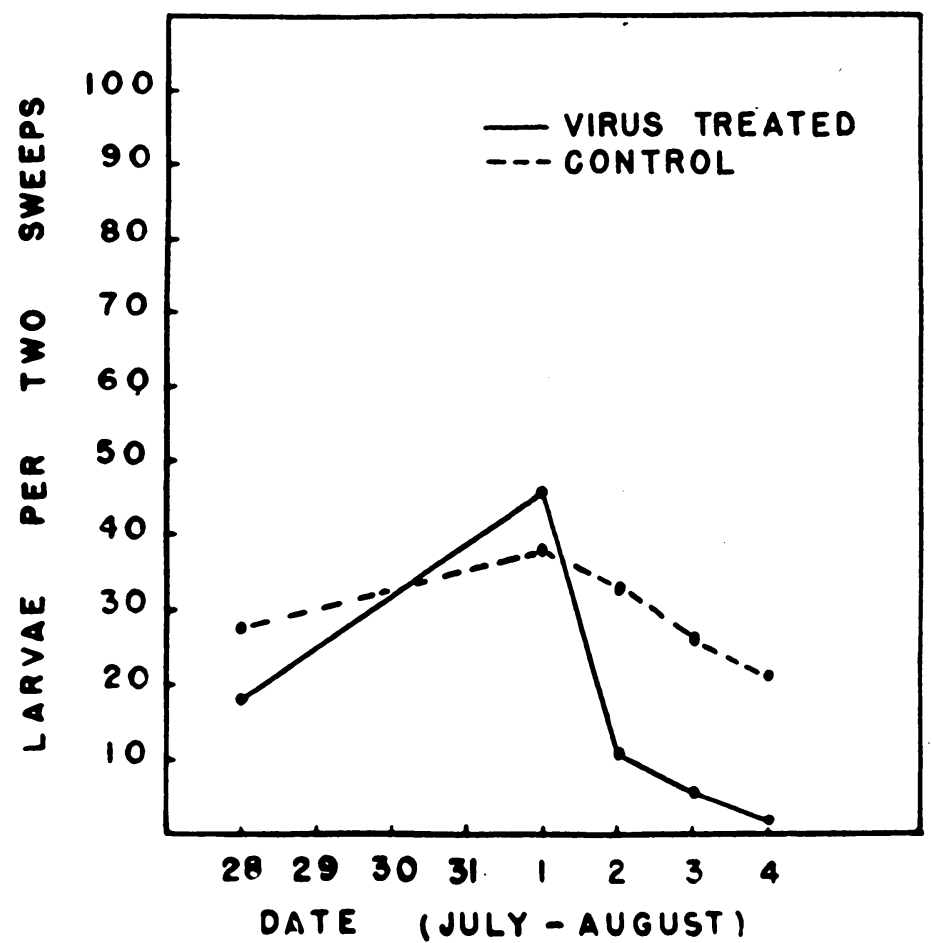

Fig. 9. The number of larvae per two sweeps in the treated and untreated (control) portions of 1949 field test 2, plot 7. Concentration of virus suspension : $25,000,000$ polyhedra per milliliter.

\section{TABLE 10}

Results of 1949 Field Test 2, Plot 7, Showing Number (Average of Two-Sweep

Samples) and Instar of Colias Larvae in Treated and Untreated Plots and the Percentage of Larvae InfFeted with Virus. Virus Applied JUly

28, 1949. Virus Concentration 25,000,000 PolyhedRa PER ML.

\begin{tabular}{|c|c|c|c|c|c|c|c|c|c|c|}
\hline \multirow{2}{*}{ Treatment } & \multirow{2}{*}{ Date } & \multicolumn{2}{|c|}{ Daily temperature } & \multicolumn{4}{|c|}{ Instar } & \multirow{2}{*}{$\begin{array}{c}\text { Total all } \\
\text { instars }\end{array}$} & \multirow{2}{*}{$\begin{array}{l}\text { Per cent } \\
\text { ISRP }\end{array}$} & \multirow{2}{*}{$\begin{array}{c}\text { Per cent } \\
\text { with } \\
\text { poly- } \\
\text { hedra }\end{array}$} \\
\hline & & Min. & Max. & $1-2$ & 3 & 4 & 5 & & & \\
\hline & & ${ }^{\circ} \mathrm{F}$ & ${ }^{\circ} \mathrm{F}$ & & & & & & & \\
\hline Treated. . & $7-28$ & 56 & 94 & 8 & 5 & 4 & 1 & 18 & 20 & 0 \\
\hline Control. & $7-28$ & 56 & 94 & 9 & 4 & 11 & 4 & 28 & 25 & 0 \\
\hline Treated. & $8-1$ & 63 & 101 & 1 & 15 & 11 & 14 & 41 & 50 & 100 \\
\hline Control. & $8-1$ & 63 & 101 & 1 & 15 & 6 & 16 & 38 & 50 & 0 \\
\hline Treated.. & $8-2$ & 59 & 103 & 1 & 5 & 3 & 2 & 11 & 70 & 100 \\
\hline Control.......... & $8-2$ & 59 & 103 & 1 & 10 & 6 & 16 & 33 & 70 & 0 \\
\hline Treated. . & $8-3$ & 56 & 105 & 0 & 3 & 2 & 1 & 6 & 80 & 100 \\
\hline Control. . & $8-3$ & 56 & 105 & 0 & 6 & 8 & 12 & 26 & 80 & 0 \\
\hline Treated....... & $8-4$ & 60 & 100 & 0 & 1 & 1 & 0 & 2 & 50 & 100 \\
\hline Control $\ldots \ldots \ldots$ & $8-4$ & 60 & 100 & 0 & 4 & 6 & 11 & 21 & 80 & 10 \\
\hline
\end{tabular}




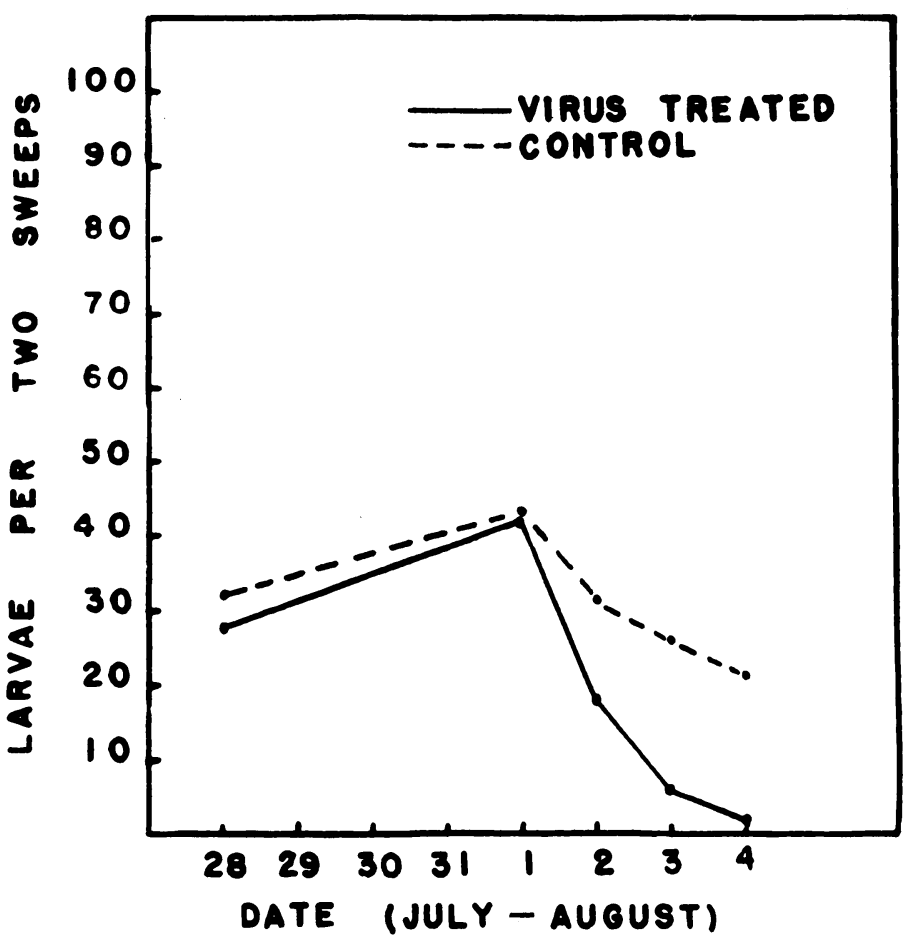

Fig. 10. The number of larvae per two sweeps in the treated and untreated (control) portions of 1949 field test 2, plot 8. Concentration of virus suspension: $50,000,000$ polyhedra per milliliter.

TABLE 11

Results of 1949 Field Test 2, Plot 8, Showing Number (Average of Two-Sweep Samples) and Instar of Colias Larvae in Treated and UnṬReated Plots and THE Percentage of Larvae InFECTEd with Virus. Virus APPLied JULY 28, 1949. Virus Concentration 50,000,000 Pol yhedra Per ML.

\begin{tabular}{|c|c|c|c|c|c|c|c|c|c|c|}
\hline \multirow{2}{*}{ Treatment } & \multirow{2}{*}{ Date } & \multicolumn{2}{|c|}{ Daily temperature } & \multicolumn{4}{|c|}{ Instar } & \multirow{2}{*}{$\begin{array}{c}\text { Total all } \\
\text { instars }\end{array}$} & \multirow{2}{*}{$\begin{array}{l}\text { Per cent } \\
\text { ISRP }\end{array}$} & \multirow{2}{*}{$\begin{array}{c}\text { Per cent } \\
\text { with } \\
\text { poly- } \\
\text { hedra }\end{array}$} \\
\hline & & Min. & Max. & $1-2$ & 3 & 4 & 5 & & & \\
\hline & & ${ }^{\circ} \mathrm{F}$ & ${ }^{\circ} \mathrm{F}$ & & & & & & & \\
\hline Treated. & $7-28$ & 56 & 94 & 5 & 13 & 9 & 1 & 28 & 20 & 0 \\
\hline Control. & $7-28$ & 56 & 94 & 9 & 11 & 9 & 3 & 32 & 20 & 0 \\
\hline Treated. & $8-1$ & 63 & 101 & 1 & 10 & 13 & 18 & 42 & 50 & 100 \\
\hline Control......... & $8-1$ & 63 & 101 & 1 & 11 & 12 & 19 & 43 & 50 & 0 \\
\hline Treated. . & $8-2$ & 59 & 103 & 1 & 5 & 4 & 8 & 18 & 80 & 100 \\
\hline Control. & $8-2$ & 59 & 103 & 0 & 13 & 6 & 12 & 31 & 70 & 0 \\
\hline Treated........ & $8-3$ & 56 & 105 & 0 & 3 & 1 & 2 & 6 & 80 & 100 \\
\hline Control......... & $8-3$ & 56 & 105 & 0 & 9 & 8 & 9 & 26 & 70 & 0 \\
\hline Treated. & $8-4$ & 60 & 100 & 0 & 1 & 0 & 1 & 2 & 50 & 100 \\
\hline Control. & $8-4$ & 60 & 100 & 0 & 7 & 6 & 8 & 21 & 70 & 0 \\
\hline
\end{tabular}


TABLE 12

Results of 1949 Field Test 3 (Airplane Application) Showing Number and Instar of Colias Larvae in Treated and Untreated Plots and the Percentage of Larvae INFECTED WITH ViRUs. VIRUs APPLIED AUGUST 17, 1949

\begin{tabular}{|c|c|c|c|c|c|c|c|c|c|c|c|c|}
\hline \multirow{2}{*}{ Treatment } & \multirow{2}{*}{ Date } & \multicolumn{2}{|c|}{ Daily temp. } & \multicolumn{6}{|c|}{ lnstar } & \multirow{2}{*}{$\begin{array}{l}\text { Total } \\
\text { all } \\
\text { instars }\end{array}$} & \multirow{2}{*}{$\begin{array}{c}\text { Per } \\
\text { cent } \\
\text { ISRP }\end{array}$} & \multirow{2}{*}{$\begin{array}{l}\text { Per cent } \\
\text { with } \\
\text { poly- } \\
\text { hedra }\end{array}$} \\
\hline & & Min. & Max. & 1 & 2 & 3 & 4 & 5 & $\begin{array}{l}\mathrm{Pu}- \\
\mathrm{pae}^{1}\end{array}$ & & & \\
\hline & & ${ }^{\circ} \mathbf{F}$ & ${ }^{\circ} \mathrm{F}$ & & & & & & & & & \\
\hline Pre-treat.. & $8-16$ & 50 & 90 & 12 & 38 & 9 & 1 & 0 & 0 & 60 & 5 & 0 \\
\hline Control. . & $8-16$ & 50 & 90 & 9 & 33 & 8 & 2 & 0 & 0 & 52 & 5 & 0 \\
\hline Treated. . & $8-17$ & 56 & 94 & 10 & 49 & 21 & 4 & 1 & 0 & 85 & 5 & 0 \\
\hline Control. . & $8-17$ & 56 & 94 & 12 & 41 & 9 & 2 & 0 & 0 & 64 & 5 & 0 \\
\hline Treated. & $8-18$ & 57 & 96 & 10 & 56 & 40 & 6 & 2 & 0 & 114 & 5 & 0 \\
\hline Control. & 8-18 & 57 & 96 & 8 & 51 & 34 & 5 & 3 & 0 & 101 & 5 & 0 \\
\hline Treated. & 8-19 & 52 & 98 & 4 & 64 & 38 & 8 & 3 & 0 & 117 & 10 & $\mathbf{0}$ \\
\hline Control. . & $8-19$ & 52 & 98 & 6 & 55 & 36 & 7 & 5 & 0 & 109 & 9 & $\mathbf{0}$ \\
\hline Treated. & $8-20$ & 52 & 100 & 4 & 65 & 35 & 19 & 4 & 0 & 127 & 11 & 20 \\
\hline Control. . & $8-20$ & 52 & 100 & 4 & 77 & 46 & 10 & 6 & 1 & 144 & 12 & 0 \\
\hline Treated. & $8-21$ & 56 & 98 & 5 & 116 & 52 & 34 & 12 & 0 & 219 & 12 & 101 \\
\hline Control. . & $8-21$ & 56 & 98 & 7 & 141 & 81 & 18 & 15 & 1 & 263 & 10 & 0 \\
\hline Treated.... . . & $8-22$ & 62 & 95 & 7 & 127 & 70 & 49 & 20 & 0 & 273 & 13 & 100 \\
\hline Control..... & $8-22$ & 62 & 95 & 4 & 128 & 83 & 84 & 29 & 2 & 330 & 12 & 10 \\
\hline Treated. & $8-23$ & 56 & 90 & 2 & 89 & 51 & 29 & 21 & 0 & 193 & 9 & 100 \\
\hline Control. . & $8-23$ & 56 & 90 & 3 & 124 & 82 & 142 & 48 & 3 & 409 & 12 & 8 \\
\hline Treated. . & $8-24$ & 50 & 93 & 0 & 25 & 17 & 12 & 5 & 0 & 59 & 19 & 100 \\
\hline Control. . & $8-24$ & 50 & 93 & 1 & 119 & 78 & 141 & 93 & 5 & 437 & 18 & 16 \\
\hline Treated. & $8-25$ & 54 & 97 & 0 & 14 & 7 & 5 & 3 & 0 & 29 & 28 & 100 \\
\hline Control... & $8-25$ & 54 & 97 & 0 & 120 & 48 & 120 & 73 & 10 & 371 & 24 & 22 \\
\hline Treated. & $8-2 b$ & 58 & 98 & 0 & 5 & 5 & 3 & 1 & 0 & 14 & 20 & 100 \\
\hline Control... & $8-26$ & 58 & 98 & 0 & 100 & 41 & 108 & 81 & 13 & 343 & 31 & 28 \\
\hline
\end{tabular}

1 Probably does not represent an accurate indication of the number of pupae actually present, since sweeping is not an adequate means of sampling pupal populations. 


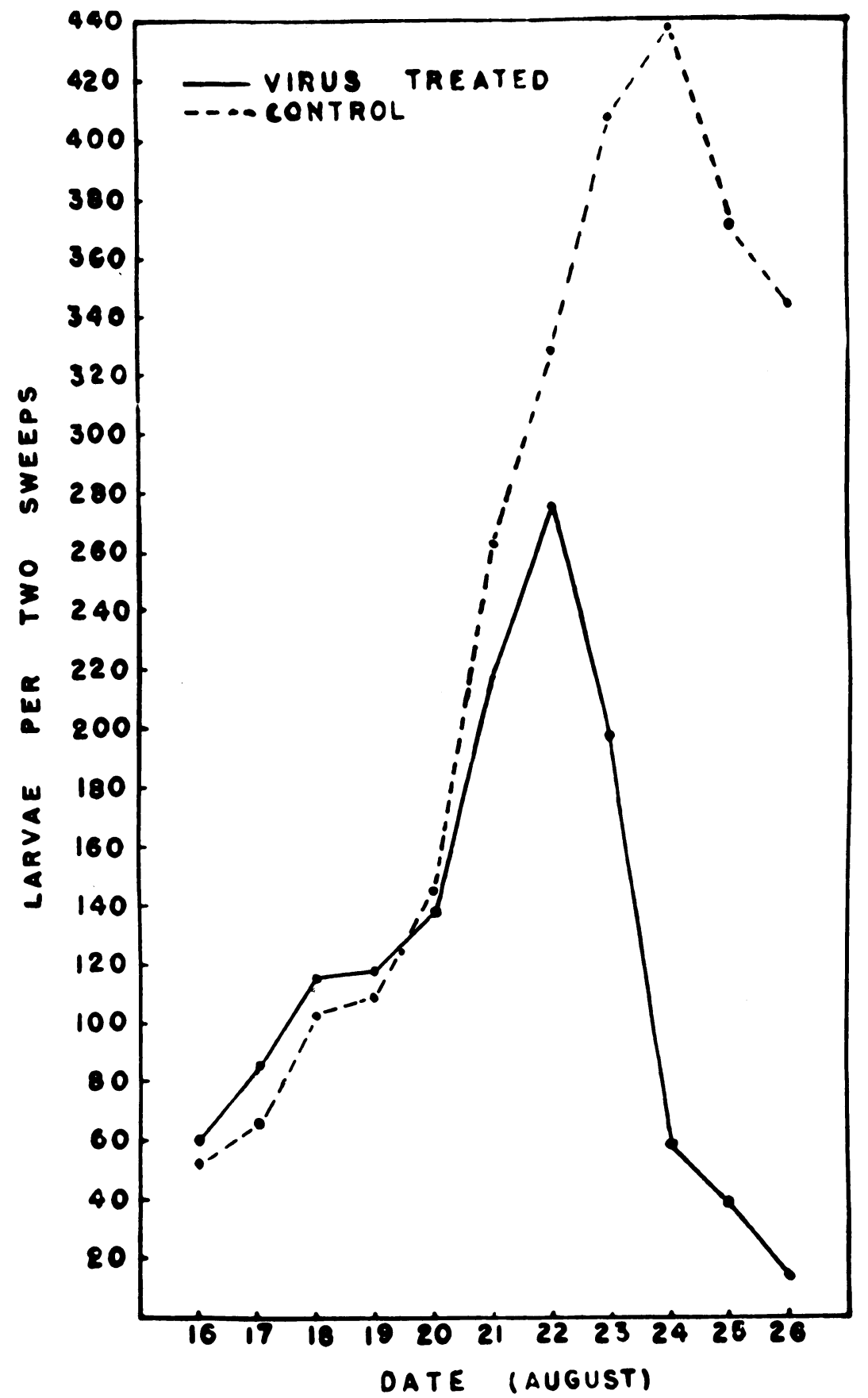

Fig. 11. The number of larvae per two sweeps in the treated and untreated portions of the field used in 1949 field test 3 (airplane application) during a 10-day period. Virus applied August 17, 1949. Concentration of virus suspension : $5,000,000$ polyhedra per milliliter. 


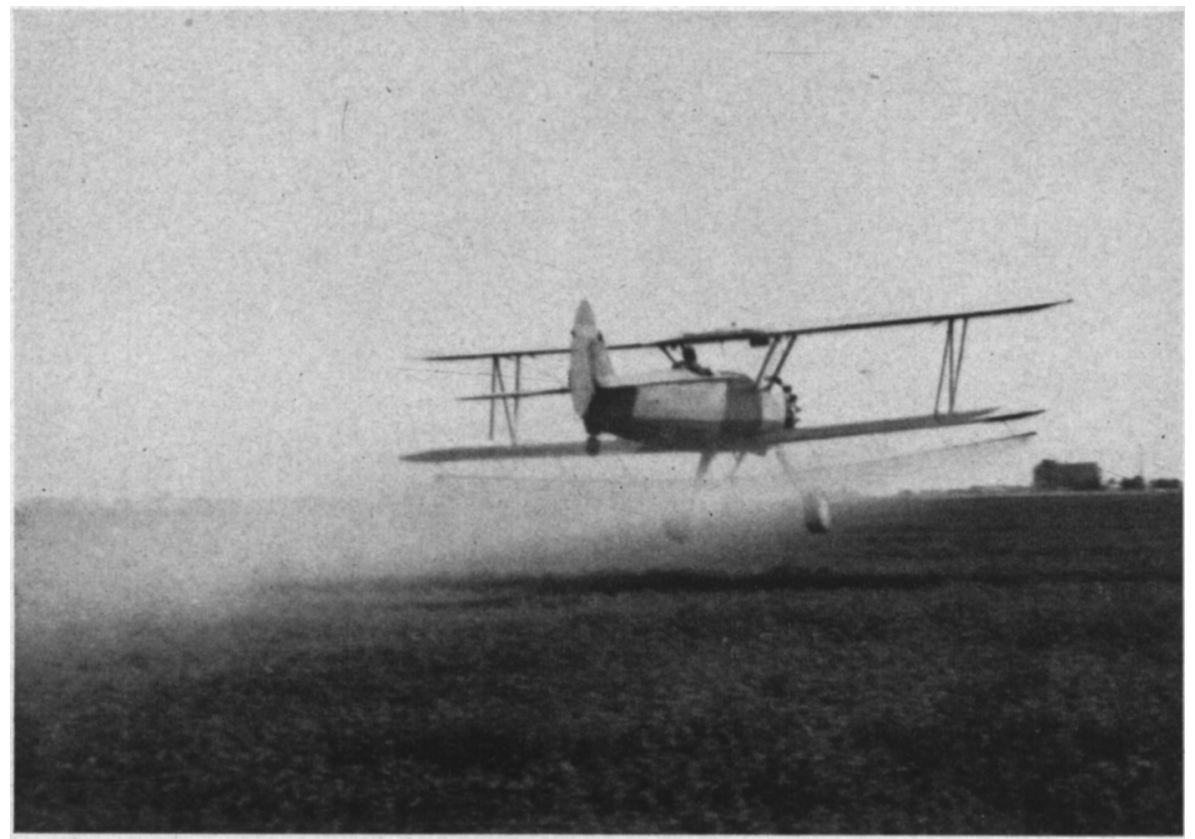

Fig. 12. Type of airplane application used in 1949 field tests 3 and 4. (Photo courtesy Ray F. Smith.)

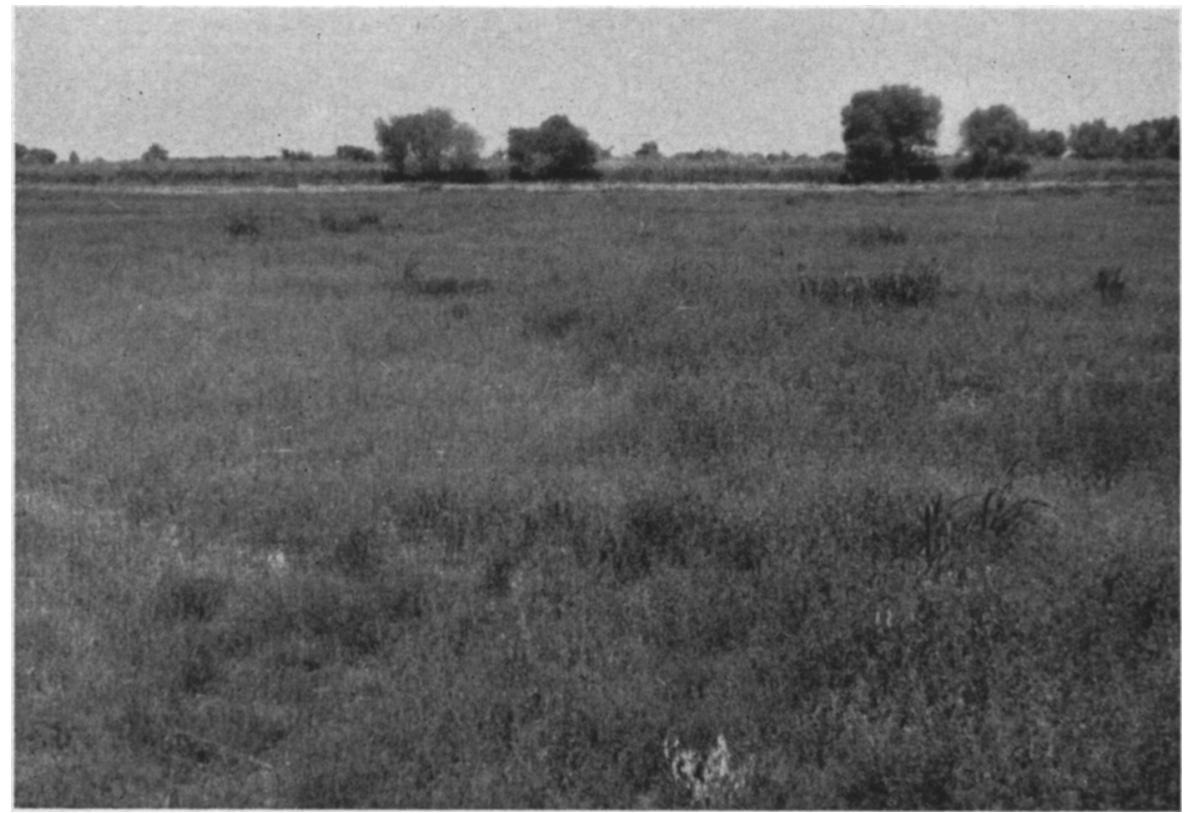

Fig. 13. Field test 3 on eighth day after application. Virus-treated portion on the right, untreated control on the left. 
TABLE 13

Results of 1949 Field Test 4 (AIrplane Application) SHowing Number and Instar of Colias Larvae in Plot A (5,000,000 Polyhedra Per ML.), Plot B $(45,000,000$

POLYHEDRA PER ML.), AND THE UNTREATted CONTROL Plot

\begin{tabular}{|c|c|c|c|c|c|c|c|c|c|c|c|}
\hline \multirow{2}{*}{ Plot } & \multirow{2}{*}{ Date } & \multicolumn{2}{|c|}{ Daily temp. } & \multicolumn{5}{|c|}{ Instar } & \multirow{2}{*}{$\begin{array}{c}\text { Total all } \\
\text { instars }\end{array}$} & \multirow{2}{*}{$\begin{array}{l}\text { Per cent } \\
\text { ISRP }\end{array}$} & \multirow{2}{*}{$\begin{array}{c}\text { Per cent } \\
\text { with } \\
\text { poly- } \\
\text { hedra }\end{array}$} \\
\hline & & Min. & Max. & 1 & 2 & 3 & 4 & 5 & & & \\
\hline & & ${ }^{\circ} \mathrm{F}$ & ${ }^{\circ} \mathrm{F}$ & & & & & & & & \\
\hline & $9-5$ & 52 & 81 & 0 & 0 & 2 & 0 & 0 & 2 & 60 & 0 \\
\hline B.... & $9-5$ & 52 & 81 & 0 & 0 & 1 & 0 & 0 & 1 & 60 & 0 \\
\hline Control.... & $9-5$ & 52 & 81 & 0 & 0 & 2 & 0 & 0 & 2 & 60 & 0 \\
\hline A. . & $9-6$ & 54 & 86 & 0 & 0 & 2 & 0 & 0 & 2 & 60 & 0 \\
\hline B....... & $9-6$ & 54 & 86 & 0 & 0 & 2 & 0 & 0 & 2 & 70 & 0 \\
\hline Control...... & $9-6$ & 54 & 86 & 0 & 0 & 2 & 0 & 0 & 2 & 70 & 0 \\
\hline A... & $9-7$ & 53 & 83 & 10 & 0 & 1 & 1 & 1 & 13 & 80 & 0 \\
\hline B...... & $9-7$ & 53 & 83 & 9 & 1 & 1 & 0 & 0 & 11 & 85 & 0 \\
\hline Control. . & $9-7$ & 53 & 83 & 11 & 0 & 1 & 0 & 0 & 12 & 75 & 0 \\
\hline A.. & $9-8$ & 59 & 97 & 12 & 2 & 1 & 1 & 0 & 16 & 50 & 0 \\
\hline B. . & $9-8$ & 59 & 97 & 11 & 3 & 0 & 0 & 0 & 14 & 55 & 0 \\
\hline Control.. & $9-8$ & 59 & 97 & 13 & 3 & 0 & 0 & 0 & 16 & 55 & 0 \\
\hline A. . & $9-9$ & 54 & 87 & 8 & 6 & 2 & 0 & 0 & 16 & 50 & 0 \\
\hline B... & $9-9$ & 54 & 87 & 9 & 5 & 1 & 0 & 0 & 15 & 60 & 0 \\
\hline Control.... & $9-9$ & 54 & 87 & 11 & 7 & 1 & 0 & 0 & 19 & 55 & 0 \\
\hline A. & $9-10$ & 55 & 89 & 9 & 5 & 1 & 0 & 0 & 15 & 70 & 0 \\
\hline B... & $9-10$ & 55 & 89 & 7 & 4 & 2 & 0 & 0 & 13 & 70 & 0 \\
\hline Control.. & $9-10$ & 55 & 89 & 9 & 8 & 1 & 0 & 0 & 18 & 70 & 0 \\
\hline A.... & $9-11$ & 56 & 88 & 10 & 7 & 1 & 0 & 0 & 18 & 75 & 0 \\
\hline B.......... & $9-11$ & 56 & 88 & 8 & 6 & 1 & 0 & 0 & 15 & 80 & 0 \\
\hline Control.... & $9-11$ & 56 & 88 & 11 & 9 & 1 & 0 & 0 & 21 & 75 & 0 \\
\hline A.. & $9-12$ & 55 & 83 & 8 & 11 & 2 & 0 & 0 & 21 & 80 & 0 \\
\hline B....... & $9-12$ & 55 & 83 & 5 & 10 & 1 & 0 & 0 & 16 & 85 & 0 \\
\hline Control. & $9-12$ & 55 & 83 & 6 & 13 & 1 & 0 & 0 & 20 & 80 & 0 \\
\hline A. & $9-13$ & 50 & 92 & 7 & 9 & 1 & 0 & 0 & 17 & 75 & 0 \\
\hline B... & $9-13$ & 50 & 92 & 7 & 11 & 1 & 0 & 0 & 19 & 85 & 0 \\
\hline Control. . & $9-13$ & 50 & 92 & 6 & 12 & 1 & 0 & 0 & 19 & 80 & 0 \\
\hline A...... & $9-14$ & 54 & 96 & 6 & 7 & 1 & 0 & 0 & 14 & 70 & 0 \\
\hline B.... & $9-14$ & 54 & 96 & 5 & 9 & 0 & 0 & 0 & 14 & 80 & 0 \\
\hline Control...... & $9-14$ & 54 & 96 & 7 & 8 & 1 & 0 & 0 & 16 & 75 & 0 \\
\hline A.. & $9-15$ & 52 & 97 & 3 & 6 & 0 & 0 & 0 & 9 & 75 & 0 \\
\hline B....... & $9-15$ & 52 & 97 & 4 & 10 & 0 & 0 & 0 & 14 & 75 & 30 \\
\hline Control. & $9-15$ & 52 & 97 & 6 & 12 & 0 & 0 & 0 & 18 & 75 & 0 \\
\hline A... & $9-16$ & 56 & 93 & 2 & 5 & 0 & 0 & 0 & 7 & 70 & 10 \\
\hline B....... & $9-16$ & 56 & 93 & 3 & 9 & 0 & 0 & 0 & 12 & 70 & 85 \\
\hline Control. & $9-16$ & 56 & 93 & 2 & 8 & 0 & 0 & 0 & 10 & 75 & 0 \\
\hline A.. & $9-17$ & 53 & 93 & 3 & 7 & 1 & 0 & 0 & 11 & 70 & 50 \\
\hline B... & $9-17$ & 53 & 93 & 3 & 8 & 0 & 0 & 0 & 11 & 65 & 100 \\
\hline Control. & $9-17$ & 53 & 93 & 2 & 11 & 0 & 0 & 0 & 13 & 70 & 0 \\
\hline A.. & $9-18$ & 50 & 100 & 2 & 9 & 0 & 0 & 0 & 11 & 65 & 100 \\
\hline B... & $9-18$ & 50 & 100 & 2 & 12 & 1 & 0 & 0 & 15 & 65 & 100 \\
\hline Control. . & $9-18$ & 50 & 100 & 1 & 15 & 0 & 0 & 0 & 16 & 70 & 0 \\
\hline
\end{tabular}

(Continued) 
TABLE 13-Concluded

\begin{tabular}{|c|c|c|c|c|c|c|c|c|c|c|c|}
\hline \multirow{2}{*}{ Plot } & \multirow{2}{*}{ Date } & \multicolumn{2}{|c|}{ Daily temp. } & \multicolumn{5}{|c|}{ Instar } & \multirow{2}{*}{$\begin{array}{c}\text { Total all } \\
\text { instars }\end{array}$} & \multirow{2}{*}{$\begin{array}{l}\text { Per cent } \\
\text { ISRP }\end{array}$} & \multirow{2}{*}{$\begin{array}{c}\text { Per cent } \\
\text { with } \\
\text { poly- } \\
\text { hedra }\end{array}$} \\
\hline & & Min. & Max. & 1 & 2 & 3 & 4 & 5 & & & \\
\hline & & ${ }^{\circ} \mathrm{F}$ & ${ }^{\circ} \mathbf{F}$ & & & & & & & & \\
\hline A... & $9-19$ & 56 & 103 & 1 & 14 & 1 & 0 & 0 & 16 & 65 & 100 \\
\hline B........ & $9-19$ & 56 & 103 & 2 & 21 & 3 & 0 & 0 & 26 & 60 & 100 \\
\hline Control............ & $9-19$ & 56 & 103 & 1 & 28 & 2 & 0 & 0 & 31 & 65 & 0 \\
\hline A... & $9-20$ & 60 & 103 & 2 & 7 & 4 & 1 & 0 & 14 & 65 & 100 \\
\hline B.... & $9-20$ & 60 & 103 & 1 & 9 & 8 & 3 & 0 & 21 & 50 & 100 \\
\hline Control. & $9-20$ & 60 & 103 & 1 & 18 & 6 & 2 & 0 & 27 & 60 & 0 \\
\hline A. $\ldots \ldots \ldots$ & $9-21$ & 61 & 104 & 1 & 5 & 7 & 3 & 0 & 16 & 50 & 100 \\
\hline B.......... & $9-21$ & 61 & 104 & 0 & 4 & 11 & 4 & 0 & 19 & 50 & 100 \\
\hline Control. & $9-21$ & 61 & 104 & 1 & 9 & 19 & 5 & 0 & 34 & 55 & 0 \\
\hline A... & $9-22$ & 62 & 107 & 0 & 3 & 14 & 3 & 0 & 20 & 50 & 100 \\
\hline B...... & $9-22$ & 62 & 107 & 0 & 4 & 9 & 3 & 0 & 16 & 50 & 100 \\
\hline Control.. & $9-22$ & 62 & 107 & 0 & 5 & 15 & 11 & 0 & 31 & 55 & 0 \\
\hline A. & $9-23$ & 62 & 107 & 0 & 2 & 9 & 1 & 0 & 12 & 50 & 90 \\
\hline B... & $9-23$ & 62 & 107 & 0 & 4 & $\mathbf{5}$ & 2 & 0 & 11 & 45 & 95 \\
\hline Control. & $9-23$ & 62 & 107 & $\mathbf{0}$. & 7 & 17 & 13 & 1 & 38 & 55 & 5 \\
\hline A..... & $9-24$ & 53 & 94 & 0 & 5 & 4 & 3 & 1 & 13 & 40 & 80 \\
\hline B... & $9-24$ & 53 & 94 & 0 & 7 & 6 & 2 & 0 & 15 & 40 & 85 \\
\hline Control. & 9-24 & 53 & 94 & 0 & 11 & 19 & 16 & 7 & 53 & 45 & 5 \\
\hline A... & $9-25$ & 54 & 76 & 0 & 6 & 5 & 4 & 1 & 16 & 45 & 70 \\
\hline B..... & $9-25$ & 54 & 76 & 0 & 6 & 5 & 4 & 1 & 16 & 40 & 75 \\
\hline Control. . & $9-25$ & 54 & 76 & 0 & 13 & 21 & 14 & 5 & 53 & 45 & 0 \\
\hline
\end{tabular}

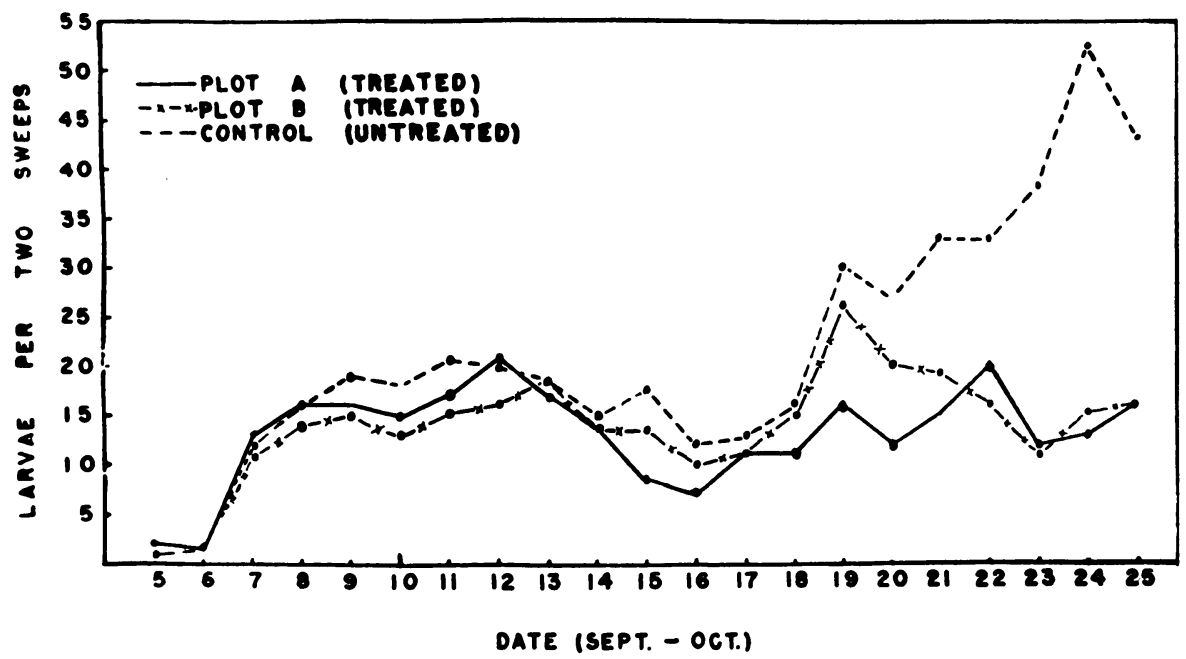

Fig. 14. The number of larvae per two sweeps in the treated and untreated portions of the field used in 1949 field test 4 (airplane application) during a 20-day period. Virus applied September 10, 1949. Concentration of virus suspension : Plot A, 5,000,000 polyhedra per milliliter; plot B, 45,000,000 polyhedra per milliliter. 

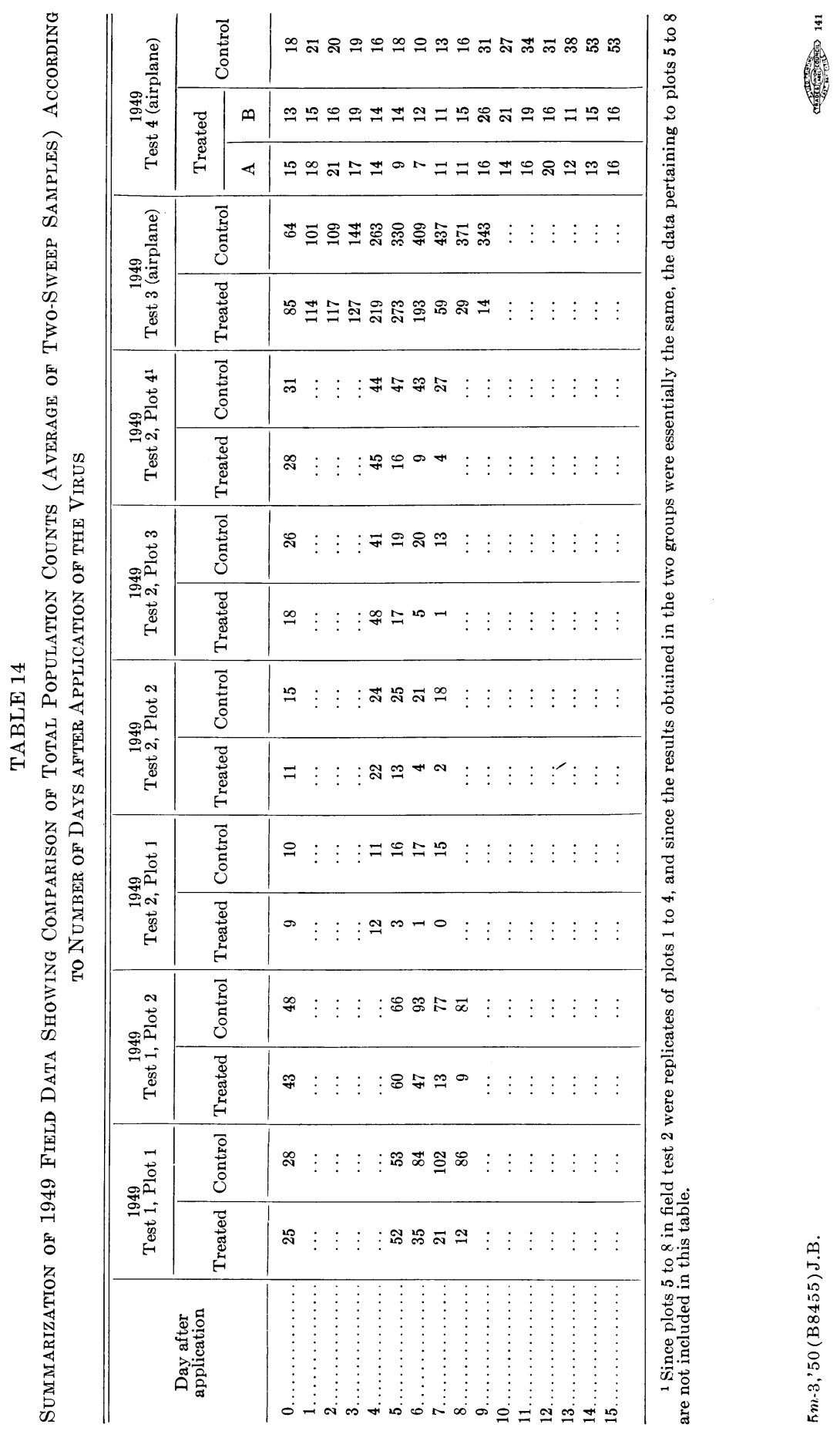

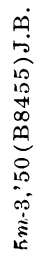



The journal Hilgardia is published at irregular intervals, in volumes of about 600 pages. The number of issues per volume varies.

Subscriptions are not sold. The periodical is sent as published only to libraries, or to institutions in foreign countries having publications to offer in exchange.

You may obtain a single copy of any issue free, as long as the supply lasts; please request by volume and issue number from:

\section{Publications Office \\ College of Agriculture \\ Berkeley 4, California}

The limit to nonresidents of California is 10 separate issues on a single order. A list of the issues still available will be sent on request. 